K A N D A I

\begin{tabular}{|l|l|l|}
\hline Volume 16 & No. 2, November 2020 & Halaman 183-204 \\
\hline
\end{tabular}

\title{
VITALITAS BAHASA TOLAKI DI KOTA KENDARI (The Vitality of Tolaki Language in Kendari)
}

\author{
Firman A. D., Asri, \& Sukmawati \\ Kantor Bahasa Provinsi Sulawesi Tenggara \\ Jalan Haluoleo, Kompleks Bumi Praja Anduonohu, Kendari, Indonesia \\ Telepon (0401)3135289, 3135287; Faksimile (0401) 3135286 \\ Pos-el: firmanad041@gmail.com
}

(Diterima: 13 Februari 2020; Direvisi: 24 Agustus 2020; Disetujui: 31 Oktober 2020)

\begin{abstract}
This research aimed to know the vitality of Tolaki language in all social domains. This was descriptive-quantitative research by using twelve research indicators. Frequency and percentage determination using SPSS program was applied to find out the level of vitality. Then, those quantitative data were synergized with the qualitative data from in-depth interview. The results showed that the average index of all indicators was $0.42 \%$ with the category is in decline. However, that number of percentages was nearing extinction. It appears as the mobility of native speakers and Tolakinese people to other regions is high since the transportation access and routes are excellent. Tolakinese people tend to be bilingual. In any social domains, Tolaki language is not or rarely used. People prefer using Indonesian. Actually, there are many documentations regarded to Tolaki language, yet many still do not know about them as they are not evenly distributed. Tolakinesspeople tend to have a positive attitude towards their language. They are proud and assume that Tolaki language is still more important than other languages. Furthermore, they also respect to the speakers of other languages and the existence of other languages in Kendari.
\end{abstract}

Keywords: language vitality, Tolaki language, language extinction, language attitude

\begin{abstract}
Abstrak
Penelitian ini bertujuan mengetahui vitalitas bahasa Tolaki dalam berbagai ranah sosial. Penelitian itu berancangan kuantitatif-desktiptif dengan menggunakan dua belas indikator penelitian. Untuk mengetahui tingkat vitalitas, digunakan perhitungan frekuensi dan persentase dengan menggunakan program SPSS. Hasil pengolahan data kuantatif tersebut disinergikan dengan pengolahan data kualitatif yang diperoleh dari wawancara mendalam. Hasil penelitian menunjukkan bahwa indeks rerata dari keseluruhan indikator berada pada angka 0,42\% dengan kategori mengalami kemunduran. Namun, angka tersebut hampir mendekati posisi terancam punah. Hal tersebut didukung oleh mobilitas penutur dan etnis Tolaki ke daerah lain termasuk tinggi karena akses dan jalur transportasi yang sangat baik. Masyarakat penutur bahasa Tolaki cenderung dwibahasawan. Dalam berbagai ranah sosial, bahasa Tolaki tidak atau jarang dipergunakan. Masyarakat masih lebih memilih menggunakan bahasa Indonesia. Jumlah dokumentasi mengenai bahasa Tolaki relatif sudah banyak, tetapi banyak yang belum mengetahui hasil dokumentasi tersebut karena tidak tersebar secara merata. Masyarakat Tolaki cenderung memiliki sikap positif terhadap bahasanya. Mereka merasa bangga dan menganggap bahasa Tolaki masih lebih penting dibandingkan dengan bahasa-bahasa lain. Selain itu, mereka juga menghargai penutur bahasa lain dan keberadaan bahasa lain di Kendari.
\end{abstract}

Kata-kata kunci: vitalitas bahasa, bahasa Tolaki, kepunahan bahasa, sikap bahasa

DOI: $10.26499 / j k . v 16 i 2.2188$

How to cite: Firman A. D., Asri, \& Sukmawati (2020). Vitalitas bahasa Tolaki di Kota Kendari. Kandai, 16(2), 183204 (DOI: $10.26499 / j k . v 16 i 2.2188$ ) 


\section{PENDAHULUAN}

Indonesia memiliki kekayaan bahasa dan budaya yang terhampar dari Sabang sampai Merauke. Telah menjadi suatu aksioma, ada bahasa daerah yang berangsur-angsur menuju kepada suatu kematian atau kepunahan. Terancam punahnya bahasa daerah umum terjadi di beberapa wilayah di Indonesia. Berdasarkan pemberitaan (Rachmawati, 2018), ada beberapa bahasa daerah yang telah mengalami kepunahan di wilayah Indonesia, di antaranya di Papua ada 2 bahasa dan di Maluku 9 bahasa.

Salah satu penyebab punahnya
bahasa daerah adalah karena ditinggalkan oleh penuturnya atau penuturnya tidak mau lagi menggunakan bahasanya dalam berbagai situasi. Hal tersebut bisa disebabkan oleh beberapa hal, antara lain adanya anggapan bahasa daerah kurang berprestise, kurang memiliki nilai ekonomi, adanya amalgamasi, dan kurangnya daya tahan akibat gempuran bahasa pendatang. Situasi-situasi tersebut biasanya terjadi di daerah perkotaan yang memiliki tingkat akulturasi budaya yang tinggi dan tempat terjadinya perbauran budaya dari berbagai suku.

Berkembangnya sebuah wilayah menjadi perkotaan menyebabkan wilayah tersebut sebagai tempat bertemunya berbagai budaya dan bahasa dan secara tidak langsung memaksa seseorang untuk menggunakan bahasa Indonesia sebagai alat komunikasi. Keadaan tersebut berimbas ke generasi berikutnya yang tidak lagi mempelajari bahasa daerah orang tua sebagai bahasa ibu, melainkan langsung mempelajari bahasa Indonesia sebagai bahasa ibu.

Kota Kendari merupakan ranah budaya dari etnis Tolaki. Berdasarkan pengamatan awal di lapangan, penutur bahasa Tolaki sudah berbaur dengan masyarakat pendatang bahkan sudah banyak terjadi pernikahan antaretnis (amalgamasi). Saat ini, seorang anak yang lahir dari pernikahan sesama etnis Tolaki belum tentu mampu berbahasa Tolaki dengan baik. Hal tersebut dipengaruhi oleh lingkungan pergaulan dan lingkungan sosial yang sudah didiami oleh etnis-etnis lain. Jadi, kemajemukan sebuah kota dapat menjadi pemicu berkurangnya penutur sebuah bahasa daerah. Umumnya, penutur aktif bahasa Tolaki di Kota Kendari kemungkinan berada pada usia empat puluh tahun ke atas. Situasi tersebut menjadi tanda awal kemerosotan sebuah bahasa. Sementara, penutur masa depan (anak-anak) dari etnis Tolaki banyak yang sudah tidak menguasai bahasa Tolaki dengan baik.

Untuk membuktikan berbagai asumsi tersebut, perlu diadakan sebuah penelitian untuk mengetahui status vitalitas bahasa Tolaki di Kota Kendari. Dengan mengetahui status vitalitas bahasa tersebut, diharapkan dapat dilakukan langkah-langkah penanganan lanjutan yang lebih tepat untuk bahasa Tolaki di Kota Kendari.

Penelitian mengenai bahasa Tolaki, sejauh pengamatan penulis, lebih banyak dikaji dari sisi linguistik deskriptif. Tulisan mengenai pemertahanan bahasa Tolaki dapat dilihat dalam "Bahasa Tolaki dari Generasi ke Generasi” (Hastuti, 2012). Dikemukakan dalam tulisan tersebut bahwa dalam kegiatan mendongeng yang biasa dilakukan oleh orang tuapenutur bahasa Tolaki-dulu telah hilang. Orang tua muda (25-35 tahun) lebih suka mendongeng dalam bahasa Indonesia karena anak-anak mereka tidak dibiasakan mendengarkan tuturan dalam bahasa Tolaki. Pada generasi ini, bahasa Tolaki sudah tidak digunakan, hanya sesekali saja pada perkumpulan tertentu. 
Penelitian lain yang menyinggung bahasa Tolaki dapat ditemui dalam "Profil Kebahasaan Nelayan Bugis di Tinobu, Sulawesi Tenggara: Pola-pola Penggunaan Bahasa" (Darmawati, 2015). Dalam tulisan tersebut dijelaskan bahwa bahasa Tolaki hidup berdampingan dengan bahasa Bugis di Tinobu dan mereka saling memengaruhi. Daerah Tinobu yang berada di Kabupaten Konawe Utara pada dasarnya adalah domain dari penutur bahasa Tolaki dan mereka telah hidup berdampingan dengan beberapa pendatang dari suku lain.

Ada beberapa penelitian mengenai vitalitas bahasa daerah di wilayah Indonesia.. Di antaranya yang dilakukan oleh Aritonang (2016) yang meneliti vitalitas bahasa Talondo di Sulawesi Barat. Hasil penelitiannya menunjukkan bahwa bahasa Talondo berada pada kriteria mengalami kemunduran. Berikutnya, ada Wagiati, dkk. (2017) yang meneliti mengenai vitalitas bahasa Sunda di Kabupaten Bandung. Hasil penelitian menunjukkan bahwa vitalitas bahasa Sunda kuat pada ranah kekeluargaan, transaksional, dan kekariban, tetapi lemah pada ranah kedinasan dan orang tidak dikenal. Penelitian vitalitas bahasa Devayan yang dituturkan di Pulau Simeulue, Aceh, juga pernah diteliti oleh Candrasari (2017). Hasilnya menunjukkan bahwa bahasa Devayan berada pada kategori stabil, tetapi mengalami kemunduran. Investigasi mengenai sikap bahasa terhadap bahasanya menunjukkan kategori positif, begitu juga sikap terhadap penutur.

Berdasarkan tinjauan pustaka tersebut, dapat dikatakan bahwa penelitian mengenai vitalitas bahasa Tolaki yang ada di Sulawesi Tenggara jarang atau belum pernah dilakukansangat jarang ditemukan. Oleh karena itu, penelitian ini dapat menjadi referensi berharga dalam melihat dan menilai perkembangan dan eksistensi bahasa Tolaki secara sosiologis. Selain itu, penelitian vitalitas bahasa daerah di Indonesia masih menjadi isu yang menarik karena sebagian besar belum diteliti tingkat vitalitasnya. Perkembangan masyarakat yang semakin modern menyebabkan ada kecenderungan meninggalkan bahasa daerah.

\section{LANDASAN TEORI}

Kepunahan sebuah bahasa disebabkan oleh tidak adanya penutur dari bahasa tersebut. Kasus kebahasaan yang paling memprihatinkan di Indonesia adalah terancam punahnya sebagian bahasa daerah. Banyak bahasa daerah di Indonesia dengan jumlah penutur yang relatif sedikit (hanya ratusan ribu) dan dari masa ke masa mengalami degradasi jumlah penutur. Masalah tersebut memang tidak terlalu nampak di permukaan. Namun, jika diamati dan ditelusuri dari segi penuturnya, khususnya penutur di kalangan anak-anak sebagai penutur masa depan, sudah banyak yang tidak terlalu menguasai, bahkan tidak menguasai lagi bahasa daerahnya. Mereka cenderung lebih memilih menggunakan bahasa Indonesia sebagai bahasa sehari-hari karena sangat bermanfaat dalam pergaulan dan pemenuhan kebutuhan ekonomi.

Kepunahan atau kematian bahasa oleh para ahli memiliki pandangan yang berbeda-beda. Ada yang menganggap bahwa kepunahan bahasa disamakan dengan peralihan/ pergeseran bahasa (language shift). Sebagaimana yang dikemukakan oleh Fasold (dalam Zahari, 2011) yang menyamakan antara kematian bahasa dan peralihan bahasa. Namun, pada 
sisi lain ia mengemukakan bahwa apabila suatu masyarakat beralih kepada sebuah bahasa baru secara total dan bahasa yang lama tidak ada lagi yang menggunakannya, kejadian seperti ini bukan hanya sekadar peralihan bahasa, melainkan inilah sebetulnya yang disebut dengan kepunahan/kematian bahasa.

Sama halnya dengan Lukman (2012) yang secara tidak langsung mengemukakan persamaan pergeseran bahasa dan kepunahan bahasa. Dia mengemukakan bahwa industrialisasi dan urbanisasi dipandang sebagai sebab-sebab utama bergeser atau punahnya suatu bahasa.

Dari pendapat-pendapat tersebut, dapat dikemukakan bahwa pergeseran bahasa dapat menyebabkan terjadinya kepunahan bahasa. Namun, tidak semua pergeseran bahasa dapat menyebabkan kepunahan bahasa karena bisa jadi hanya terjadi perpindahan penutur atau hanya punah di tempat rantaunya, tetapi masih dipergunakan di wilayah asalnya.

Pergeseran bahasa terjadi karena suatu peguyuban (komunitas) meninggalkan suatu bahasa sepenuhnya untuk beralih ke bahasa lain. Bila pergeseran sudah terjadi, warga peguyuban secara kolektif memilih bahasa baru (Sumarsono, 2017). Dalam situasi inilah, biasanya bahasa yang ditinggalkan mengalami kepunahan, apalagi bahasa yang ditinggalkan tersebut dianggap oleh penuturnya tidak berprestise.

Menurut UNESCO dalam Inayatusshalihah (2018), bahasa dikatakan terancam punah ketika penuturnya berhenti menggunakannya, digunakan di ranah komunikasi yang semakin berkurang jumlahnya, dan berhenti diwariskan dari satu generasi ke generasi selanjutnya. Jika sebuah bahasa kehilangan seluruh penuturnya, bahasa itu menjadi punah atau mati. Crystal (2003) mengemukakan, "To say that a language is dead is like saying that a person is dead. It could be no other way - for languages have no exixtence without people. A language dies when nobody speaks it anymore." Zahari (2011) berpendapat bahwa istilah kematian bahasa adalah apabila terjadi kematian penutur terakhir dari suatu bahasa. Istilah ini juga dapat digunakan apabila seseorang atau suatu masyarakat beralih secara total dari bahasa ibunya ke bahasa lain dan tidak ada seorang pun di dunia yang masih menggunakan bahasa itu.

Umumnya, bahasa daerah memiliki vitalitas yang rendah karena ketidakmampuannya dalam memasuki berbagai ranah pengetahuan. Vitalitas suatu bahasa terlihat dari keunggulan eksternal (jumlah penutur bahasa) dan internalnya (word entry yang dimilikinya) (Candrasari, 2017). Ketidakmampuan bahasa daerah memasuki berbagai ranah pengetahuan berakibat semakin menurunnya jumlah penutur, khususnya di kalangan kaum muda. Penutur tentu menginginkan alat komunikasi yang dapat mengakomodasi berbagai kebutuhan dan keperluan di dunia yang semakin kompleks. Bahasabahasa daerah di Indonesia umumnya tidak dapat mengemban tugas tersebut sehingga sebagian besar penutur bahasa daerah memilih bahasa lain yang lebih akomodatif. Akhirnya, pilihan bahasa jatuh ke bahasa Indonesia sebagai bahasa persatuan dan bahasa pergaulan antarsuku yang dapat digunakan dan dipahami oleh hampir seluruh masyarakat Indonesia.

Untuk mengetahui vitalitas sebuah bahasa, perlu dilakukan penelitian terhadap penuturnya — salah satunya dengan cara survei. Survei pemetaan vitalitas bahasa-bahasa di Indonesia akan memberikan tiga informasi. Pertama, 
bagaimana bahasa-bahasa etnik di Indonesia berinteraksi dan saling memengaruhi serta bagaimana bahasabahasa yang dominan dalam suatu kawasan masyarakat multibahasa, seperti di wilayah timur Indonesia, memengaruhi bahasa-bahasa kecil. Kedua, dalam perspektif diversitas, survei pemetaan vitalitas bahasa akan menyodorkan fakta mengenai lanskap status kemajemukan bahasa di Indonesia. Tidak hanya dalam hal jumlah dan sebaran, tetapi juga seberapa kuatnya ketahanan budaya masyarakat pemakai bahasanya. Ketiga, survei pemetaan vitalitas bahasa ini juga akan memperlihatkan pola-pola hubungan antara mobilitas penutur dalam kegiatan ekonomi, pendidikan, jenis pekerjaan di ruang publik dengan mekanisme dan profil pemertahanan bahasa suatu masyarakat pemilik bahasa ibu (Ibrahim, 2011).

Berbagai penyebab kepunahan dikemukakan oleh beberapa ahli dengan berbagai sudut pandang. Umumnya, mereka mengemukakan bahwa kepunahan sebuah bahasa bisa disebabkan oleh beberapa faktor (Tondo (2009), yaitu pengaruh bahasa mayoritas tempat bahasa daerah tersebut digunakan; kondisi masyarakat penutur yang bilingual/multilingual; globalisasi; migrasi penduduk; perkawinan antaretnis; bencana alam/musibah; kurangnya penghargaan terhadap bahasa etnis sendiri; kurangnya intensitas komunikasi berbahasa daerah dalam berbagai ranah; faktor ekonomi; dan faktor bahasa Indonesia.

Faktor-faktor penyebab punahnya sebuah bahasa dapat saja berbeda antara satu bahasa dengan bahasa lain. Hal tersebut sangat bergantung pada situasi dan kondisi lingkungan tempat bahasa tersebut berada. Kemungkinan semua faktor atau hanya sebagian faktor tersebut terjadi di Indonesia, bahkan juga bisa bertambah-seperti faktor prestise.

Ada beberapa pendapat dari para pakar mengenai indikator dan tingkat vitalitas sebuah bahasa. Dari berbagai pendapat tersebut, umumnya mempertimbangkan tiga faktor utama, yaitu penutur bahasa, penggunaan bahasa, dan situasi dan kondisi penggunaan bahasa (faktor eksternal). Bahasa melekat pada diri manusia sebagai penutur. Sebuah bahasa semakin banyak yang menuturkannya akan semakin kuat vitalitasnya. Jumlah penutur yang sedikit pun bisa kuat vitalitasnya jika ia berada dalam wilayah yang jauh dari akses budaya lain dan sulit dijangkau. Adanya interaksi dengan penutur bahasa lain menjadi langkah awal terjadinya pembauran budaya yang dapat mengarah ke pergeseran bahasa.

Untuk mengetahui tingkat vitalitas sebuah bahasa, dibutuhkan sebuah kriteria yang dapat dijadikan patokan dalam penilaian dan pengategorian. Pada tahun 2003, UNESCO (Inayatusshalihah, 2018) menetapkan sembilan kriteria yang digunakan untuk penentuan tingkat ancaman kepunahan bahasa dengan mengukur vitalitas bahasa, yaitu (1) transmisi bahasa antargenerasi, (2) jumlah absolut penutur, (3) proporsi penutur dalam total populasi, (4) ranah penggunaan bahasa, (5) respon terhadap ranah dan media baru, (6) bahan pendidikan bahasa dan literasi, (7) sikap dan kebijakan pemerintah, termasuk status resmi dan penggunaan bahasa, (8) sikap anggota masyarakat terhadap bahasanya, dan (9) jumlah dan kualitas dokumentasi. Kesembilan faktor inilah yang kemudian dikembangkan dan dimodifikasi yang dijadikan indikator dalam penelitian ini.

Skala yang paling sering digunakan secara luas adalah skala yang ditetapkan oleh Wurm dalam Crystal 
(2003) yang mempunyai lima tingkat keterancaman bahasa sebagai berikut.

1) Potentially endangered, yakni memiliki potensi besar menjadi bahasa yang punah.

2) Endangered, yakni terancam punah karena sangat sedikit penutur muda yang tetap menggunakan bahasa ibunya. Penutur fasih bahasa ini hanya penutur dewasa.

3) Severely endangered, yakni benarbenar terancam karena penutur aktif adalah kelompok usia di atas 50 tahun.

4) Nearly extinct, yakni dalam kondisi sekarat karena penuturnya adalah orang-orang yang sangat tua.

5) Extinct, yakni yang sudah mati karena tidak lagi memiliki penutur.

Kelima skala tersebut dimodifikasi untuk dijadikan dasar dalam penentuan kriteria vitalitas bahasa dalam penelitian - sebagaimana yang dikemukakan pada bagian Metode Penelitian.

\section{METODE PENELITIAN}

Penelitian ini bersifat deskriptifkuantitatif. Pengumpulan data dilaksanakan di Kota Kendari yang merupakan domain dari penutur bahasa Tolaki. Waktu penelitian dimulai dari Januari sampai dengan Oktober tahun 2019.

Instrumen penelitian menjadi unsur utama dalam melaksanakan penelitian ini-dalam bentuk pertanyaan/kuesioner. Ada beberapa pertanyaan yang diberikan kepada responden berkaitan dengan keberadaan bahasa Tolaki di Kendari. Beberapa poin tersebut, yakni mobilitas informan pada posisi relatif, kota-desa; kedwibahasaan responden; penggunaan bahasa di ranah keluarga; penggunaan bahasa antargenerasi; penggunaan bahasa di ranah transaksi; penggunaan bahasa pada ekspresi tulis; penggunaan bahasa untuk mengungkapkan ekspresi perasaan; penggunaan bahasa di ranah keagamaan/adat; penggunaan bahasa di lembaga pemerintah/lembaga swasta; penggunaan bahasa di ranah pendidikan; penggunaan bahasa di ranah dokumentasi; dan sikap bahasa (kebanggan dan kesetiaan bahasa).

Objek penelitian ini adalah penutur bahasa Tolaki yang berdomisili di Kota Kendari. Jumlah responden yang menjadi target penelitian sebanyak 64 orang. Dari 64 responden tersebut, dapat diklasifikasi ke dalam berbagai karakteristik, seperti jenis kelamin, usia, pendidikan, pekerjaan, dan lama domisili di tempat pengambilan data.

Pengumpulan data menggunakan teknik angket (kuesioner), observasi, dan wawancara. Data primer diperoleh dengan menggunakan kuesioner. Materi kuesioner mengandung data pribadi responden dan data situasi kebahasaan. Bentuk kuesioner yang digunakan adalah kuesioner tertutup dengan dua jawaban, yaitu ya dan tidak.

Data kuantitatif yang diperoleh dengan menggunakan kuesioner dianalisis secara deskriptif berdasarkan perhitungan frekuensi dan persentase. Selanjutnya, data diolah dengan program SPSS. Hasil pengolahan data kualitatif ini disinergikan dengan pengolahan data kualitatif yang dipeloleh dari wawancara mendalam. Wawancara dilakukan dengan dua orang informan dari etnis Tolaki, yakni Bapak Ramis Rauf (lakilaki, 29 tahun) dan Bapak Arsamid (lakilaki, 80 tahun).

Dalam penelitian ini digunakan kriteria vitalitas bahasa yang diukur berdasarkan nilai rerata, yaitu sangat terancam $(0,0-0,20)$; terancam $(0,21-$ $0,40)$; mengalami kemunduran $(0,41-$ $0,60)$; stabil, mantap, tetapi berpotensi mengalami kemunduran $(0,61-0,80)$; dan aman $(0,81-1,00)$. Kriteria ini 
didasarkan pada konvensi perserta dan narasumber pada kegiatan "Konsinyasi Bahasa Terancam Punah" di Ciawi pada tahun 2011 (Inayatusshalihah, 2018).

\section{PEMBAHASAN}

\section{Komposisi Responden}

Responden dalam kajian ini berjumlah 64 orang dari berbagai jenjang umur, pendidikan, dan pekerjaan. Semua responden bersuku Tolaki dan menetap di Kota Kendari. Ada beberapa responden dilahirkan di luar Kota Kendari, tetapi masih di wilayah yang berpenutur bahasa Tolaki, dan ada juga satu responden yang dilahirkan di luar Sulawesi Tenggara. Komposisi responden dapat dilihat pada tabel berikut.

Tabel 1

Karakteristik Responden

\begin{tabular}{|c|c|c|c|}
\hline \multirow{2}{*}{\multicolumn{2}{|c|}{ Karakteristik }} & \multicolumn{2}{|c|}{$\begin{array}{l}\text { Frekuensi } \\
\text { dan } \\
\text { Persentase }\end{array}$} \\
\hline & & \multirow{2}{*}{$\begin{array}{c}\mathbf{F} \\
26 \\
\end{array}$} & \multirow{2}{*}{$\begin{array}{c}\% \\
40,63 \\
\end{array}$} \\
\hline Jenis & Laki-laki & & \\
\hline Kelamin & Perempuan & 38 & 59,37 \\
\hline & Total & 64 & 100,00 \\
\hline \multirow{4}{*}{$\begin{array}{l}\text { Kelompok } \\
\text { Usia }\end{array}$} & $<25$ Tahun & 28 & 43,75 \\
\hline & $25-50$ Tahun & 30 & 46,87 \\
\hline & $>50$ Tahun & 6 & 9,38 \\
\hline & Total & 64 & 100,00 \\
\hline \multirow{2}{*}{$\begin{array}{l}\text { Suku } \\
\text { Bangsa }\end{array}$} & Tolaki & 64 & 100,00 \\
\hline & Total & 64 & 100,00 \\
\hline \multirow[t]{5}{*}{ Pendidikan } & SD & 0 & 0,00 \\
\hline & SLTP & 2 & 3,13 \\
\hline & SLTA & 41 & 64.06 \\
\hline & $\begin{array}{l}\text { Perguruan } \\
\text { Tinggi }\end{array}$ & 21 & 32,81 \\
\hline & Total & 64 & 100,00 \\
\hline \multirow[t]{6}{*}{ Pekerjaan } & Pegawai & 24 & 37,50 \\
\hline & Wiraswasta & 10 & 15,63 \\
\hline & Pelajar & 22 & 34,37 \\
\hline & IRT & 7 & 10,94 \\
\hline & $\begin{array}{l}\text { Tidak } \\
\text { Menjawab }\end{array}$ & 1 & 1,56 \\
\hline & Total & 64 & 100,00 \\
\hline \multirow{3}{*}{$\begin{array}{l}\text { Lama } \\
\text { Tinggal }\end{array}$} & $<5$ Tahun & 4 & 6,25 \\
\hline & $5-10$ Tahun & 16 & 25,00 \\
\hline & $>10$ Tahun & 40 & 62,50 \\
\hline
\end{tabular}

\begin{tabular}{c|l|c|c}
\hline & $\begin{array}{l}\text { Tidak } \\
\text { Menjawab }\end{array}$ & 4 & 6,25 \\
\cline { 2 - 4 } & Total & $\mathbf{6 4}$ & $\mathbf{1 0 0 , 0 0}$ \\
\hline \multirow{2}{*}{ Bahasa Ibu } & Bahasa Tolaki & 31 & 48,44 \\
\cline { 2 - 4 } & $\begin{array}{l}\text { Bahasa } \\
\text { Indonesia }\end{array}$ & 32 & 50,00 \\
\cline { 2 - 4 } & Bahasa Bugis & 1 & 1,56 \\
\cline { 2 - 4 } & Total & $\mathbf{6 4}$ & $\mathbf{1 0 0 , 0 0}$ \\
\hline
\end{tabular}

Ada hal menarik yang perlu dikomentari pada tabel di atas, yakni pada subvariabel bahasa ibu. Ada seorang responden $(1,56 \%)$ yang memiliki bahasa ibu bahasa Bugis walaupun secara genetik bersuku Tolaki. Selain itu, yang berbahasa ibu bahasa Indonesia ada 31 orang $(48,44 \%)$. Jadi, dalam penelitian ini walaupun semua responden bersuku Tolaki, tetapi tidak semua berbahasa ibu bahasa Tolaki. Mereka umumnya menguasai dua bahasa daerah, bahasa Bugis dan bahasa Tolaki.

Bahasa Bugis, walaupun sebagai bahasa pendatang, memiliki pengaruh yang sangat besar dalam kehidupan sosial budaya masyarakat Kendari pada khususnya, dan Sulawesi Tenggara pada umumnya. Bahkan, di beberapa kabupaten, bahasa Bugis menjadi bahasa pergaulan masyarakat. Penguasaan bahasa Indonesia sebagai bahasa pertama yang diperoleh oleh responden umumnya disebabkan karena mereka berdomisili di kota. Kota sebagai wilayah majemuk membutuhkan alat komunikasi yang dapat dipahami oleh semua kalangan dan etnis. Solusi untuk masalah tersebut tentunya adalah bahasa Indonesia. Selain itu, di lingkungan rumah tangga dan tetangga, bahasa Indonesia menjadi bahasa pergaulan karena dapat digunakan/dipahami oleh berbagai suku dan etnis.

\section{Vitalitas Bahasa Tolaki}

Berdasarkan hasil penghitungan indeks, nilai indeks tiap indikator berada pada kisaran 0,05 sampai 0,74. Nilai indeks tertinggi 0,74 berada pada 
indikator sikap bahasa, sedangkan indeks terendah 0,05 pada indikator ranah pendidikan. Nilai 0,74 pada indikator sikap bahasa menunjukkan bahwa penghargaan masyarakat Tolaki terhadap bahasanya sama pentingnya dengan penghargaan terhadap bahasa pendatang. Masyarakat Tolaki termasuk etnis yang menerima kedatangan etnis lain dengan ramah. Hal tersebut dapat dilihat dalam kehidupan sosial mereka yang hidup rukun bertetangga dengan beberapa etnis. Namun, di sisi lain, perbauran mereka dengan etnis-etnis lain berpengaruh terhadap penguasaan bahasa Tolaki, khususnya kepada anakaanak dan remaja. Mereka dengan terpaksa harus berkomunikasi dalam bahasa Indonesia dan menjadikan bahasa Indonesia sebagai bahasa ibu mereka karena kondisi lingkungan yang heterogen. Etnis Tolaki lebih memilih menggunakan bahasa Indonesia dalam berkomunikasi dan mengurangi porsi penggunaan bahasa Tolaki. Ini disebabkan karena kondisi Kendari yang sangat majemuk yang tidak memungkinkan etnis Tolaki menggunakan bahasa mereka.

Nilai yang terendah adalah 0,05 pada indikator ranah pendidikan menunjukkan bahwa penggunaan bahasa Tolaki dalam ranah pendidikan, khususnya sekolah, semakin terpinggirkan. Kota Kendari merupakan habitat penutur bahasa Tolaki karena itu sekolah-sekolah sebaiknya membantu mengembangkan dan peduli dengan keberadaan bahasa Tolaki. Bahasa pelajar yang berasal dari suku Tolaki seharusnya diwajibkan menguasai bahasa Tolaki untuk masuk ke sebuah sekolah. Sementara, pelajar yang bukan penutur bahasa Tolaki sebaiknya diperkenalkan dengan bahasa Tolaki. Tujuannya adalah untuk menumbuhkan rasa saling harga-menghargai antaretnis yang ada di Kota Kendari. Karena kurangnya perhatian pemerintah terhadap bahasa Tolaki, khususnya dalam ranah pendidikan, menyebabkan adanya pandangan bahwa penggunaan bahasa Tolaki dalam kehidupan masyarakat kurang urgen.

Demikian pula nilai indeks pada indikator-indikator lain yang berada pada angka 0,30 menempatkannya pada posisi antara terancam punah dan sangat terancam. Nilai rerata indeks kumulatif dari perhitungan adalah 0,36 . Itu artinya bahasa Tolaki mengarah pada kategori terancam punah untuk wilayah Kota Kendari. Perhatikan tabel indeks kumulatif dan indeks per variabel berikut berdasarkan statistik deskriptif.

Tabel 2

Indeks Kumulatif

\begin{tabular}{l|l|l}
\hline \multicolumn{1}{c|}{ Variabel } & $\mathrm{N}$ & Mean \\
\hline Mobilitas Responden & 64 & 0,32 \\
\hline Kedwibahasaan & 64 & 0,73 \\
\hline Ranah Keluarga & 64 & 0,50 \\
\hline Antargenerasi & 64 & 0,40 \\
\hline Transaksi & 64 & 0,37 \\
\hline Ekspresi Tulis & 64 & 0,30 \\
\hline Perasaan & 64 & 0,30 \\
\hline Keagamaan/Adat & 64 & 0,45 \\
\hline Pemerintah/Lembaga Swasta & 64 & 0,09 \\
\hline Pendidikan & 64 & 0,05 \\
\hline Dokumentasi & 64 & 0,10 \\
\hline Sikap Bahasa & 64 & 0,74 \\
\hline Total & $\mathbf{6 4}$ & $\mathbf{0 , 3 6}$ \\
\hline
\end{tabular}

Berikut uraian gambaran vitalitas bahasa Tolaki di Kendari pada tiap-tiap indikator.

\section{Mobilitas}

Variabel mobilitas responden berkaitan dengan intensitas informan keluar daerah dan melakukan kontak dengan penutur bahasa lain. Tingginya 
intensitas mobilitas informan akan berpengaruh terhadap bahasa yang dikuasai. Dalam kaitannya dengan vitalitas bahasa, semakin sering penutur melakukan perjalanan keluar daerah atau melakukan kontak dengan penutur bahasa lain dapat menyebabkan terjadinya pergeseran bahasa. Pergeseran tersebut bisa terjadi dalam peminjaman kosakata. Pengaruhnya dapat menyebabkan munculnya ancaman kepunahan terhadap bahasa karena komunikasi antara penutur bahasa yang berbeda mengharuskan pemilihan satu bahasa yang dapat dipahami oleh kedua penutur sebagai alat komunikasi.

Dalam kasus bahasa Tolaki yang ada di Kota Kendari, dapat dipastikan bahwa mobilitas masyarakatnya tinggi karena didukung oleh fasilitas jalan yang sudah sangat layak. Sebagai pusat perekonomian, Kota Kendari juga pasti akan menarik perhatian dari masyarakat yang berpenutur bahasa lain untuk datang mengadu nasib. Jalur dan arus transportasi yang beragam, seperti darat, laut, dan udara, memudahkan masyarakat setempat dan masyarakat penutur bahasa lain untuk memasuki wilayah Kota Kendari. Sebagai kota terbesar di Sulawesi Tenggara, pertemuan berbagai etnis sudah sangat lazim terjadi.

Selain itu, ada juga sebagian masyarakat Tolaki yang bepergian ke daerah lain (keluar Kendari dan Sulawesi Tenggara). Hal tersebut biasanya dilakukan karena tugas kantor, pendidikan, atau ikut dengan suami/istri yang kadang menyebabkan mereka jarang kembali ke Kendari.

Kota Kendari saat ini tidak hanya didominasi oleh penutur Tolaki, tetapi dihuni oleh beberapa suku dengan membawa bahasa daerahnya yang jumlahnya relatif banyak. Sebut saja dua suku, yakni suku Muna dan suku Bugis. Kedua suku tersebut hampir mengisi seluruh sendi kehidupan di Kota Kendari. Mulai dari pedagang kaki lima sampai ke pemerintahan.

Berikut pengakuan responden mengenai mobilitas mereka yang menyebabkan terjadinya kontak bahasa dengan penutur lain

Tabel 3

Mobilitas Responden

\begin{tabular}{|c|c|c|c|}
\hline Pertanyaan & $\begin{array}{c}\text { Pilihan } \\
\text { Jawaban }\end{array}$ & $\mathbf{F}$ & $\%$ \\
\hline \multirow{3}{*}{$\begin{array}{l}\text { Pernah bepergian } \\
\text { ke daerah } \\
\text { berbahasa lain? }\end{array}$} & $\mathrm{Ya}$ & 47 & 73,44 \\
\hline & Tidak & 17 & 26,56 \\
\hline & Total & 64 & 100,00 \\
\hline \multirow{3}{*}{$\begin{array}{l}\text { Etnis Saudara } \\
\text { pernah bepergian } \\
\text { ke luar kota? }\end{array}$} & $\mathrm{Ya}$ & 52 & 81,25 \\
\hline & Tidak & 12 & 18,75 \\
\hline & Total & 64 & 100,00 \\
\hline \multirow{3}{*}{$\begin{array}{l}\text { Etnis Saudara } \\
\text { berpindah-pindah } \\
\text { tempat? }\end{array}$} & $\mathrm{Ya}$ & 15 & 23,44 \\
\hline & Tidak & 49 & 76,56 \\
\hline & Total & 64 & 100,00 \\
\hline \multirow{3}{*}{$\begin{array}{l}\text { Jauhkah jarak dari } \\
\text { tempat Saudara } \\
\text { dengan tempat } \\
\text { yang berbahasa } \\
\text { lain? }\end{array}$} & $\mathrm{Ya}$ & 20 & 31,25 \\
\hline & Tidak & 44 & 68,75 \\
\hline & Total & 64 & 100,00 \\
\hline \multirow{3}{*}{$\begin{array}{l}\text { Mudahkah } \\
\text { transportasi dan } \\
\text { komunikasi } \\
\text { dengan tempat } \\
\text { lain? }\end{array}$} & $\mathrm{Ya}$ & 53 & 82,81 \\
\hline & Tidak & 11 & 17,19 \\
\hline & Total & 64 & 100,00 \\
\hline \multirow{3}{*}{$\begin{array}{l}\text { Banyak etnis lain } \\
\text { yang berkunjung } \\
\text { ke tempat } \\
\text { Saudara? }\end{array}$} & $\mathrm{Ya}$ & 53 & 82,81 \\
\hline & Tidak & 11 & 17,19 \\
\hline & Total & 64 & 100,00 \\
\hline
\end{tabular}

Berdasarkan tabel tersebut dapat dikemukakan bahwa mobilitas penutur bahasa Tolaki di Kendari menunjukkan angka yang tinggi. Hal tersebut menandakan bahwa kontak bahasa yang terjadi antara penutur bahasa Tolaki dengan penutur bahasa daerah lain cenderung tinggi. Jalur transportasi yang sudah sangat baik menjadi faktor utama tingginya angka tersebut.

Etnis Tolaki bukanlah etnis perantau. Sebagaimana yang dikemukakan oleh Taridala (2005) bahwa "tidak ada kabar atau catatan yang bisa menceritakan bagaimana etnik ini, secara berkelompok-baik spontan maupun terorganisir-meninggalkan 
kampung halaman mereka untuk merantau ke negeri orang dengan tujuan membangun kehidupan permanen bersama warga asli setempat dalam tempo yang tidak ditentukan". Pernyataan itu terbukti pada pertanyaan poin 3 yang menunjukkan bahwa etnis Tolaki bukanlah etnis yang suka berpindah-pindah tempat, baik dalam kawasan Kendari maupun ke luar Kendari (di luar dari wilayah sukunya). Berdasarkan kondisi tersebut, etnis Tolaki lebih cenderung menerima dan menyerap kebudayaan lain, termasuk dalam hal bahasa.

\section{Kedwibahasaan}

Kedwibahasaan atau bilingualism berkenaan dengan penggunaan dua bahasa atau lebih. Kedwibahasaan merupakan salah satu fenomena kebahasaan yang ditimbulkan oleh kontak bahasa antara satu bahasa dengan bahasa yang lain. Sebagaimana yang dikemukakan oleh Lukman (2012) bahwa seorang dwibahasawan adalah orang yang memiliki kemampuan di dalam dua bahasa atau lebih, atau minimal mempunyai kemampuan dalam bahasa kedua. Sumarsono (2017) mengemukakan bahwa bilingualism (kedwibahasawan) mengacu pada pemilikan kemampuan seorang penutur atas sekurang-kurangnya B1 dan B2 meskipun kemampuannya atas B2 itu hanya sampai pada batas yang minimum.

Sebagaimana penjelasan pada variabel sebelumnya bahwa Kendari sebagai wiilayah tutur bahasa Tolaki hidup berdampingan dengan beberapa bahasa daerah lain, di antaranya yang mayoritas adalah bahasa Muna dan bahasa Bugis. Adanya dua bahasa yang berdampingan secara tidak langsung memaksa mereka untuk mencari bahasa penghubung yang bisa mereka pahami dalam berkomunikasi. Tentu saja, pilihan itu ada pada bahasa Indonesia. Akibatnya, dari peristiwa itu memunculkan gejala kedwibahasaan dalam masyarakat. Komunikasi verbal dalam masyarakat Kendari akan menggunakan bahasa Indonesia apabila melibatkan penutur bahasa daerah lain. Tingkat kedwibahasaan etnis Tolaki di Kendari dapat dilihat pada tabel di bawah.

Tabel 4

Kedwibahasaan

\begin{tabular}{|c|c|c|c|}
\hline \multicolumn{4}{|c|}{ Reawioanasaan } \\
\hline Pertanyaan & $\begin{array}{c}\text { Pilihan } \\
\text { Jawaban }\end{array}$ & $\mathbf{F}$ & $\%$ \\
\hline \multirow{3}{*}{$\begin{array}{l}\text { Saudara menguasai } \\
\text { bahasa Tolaki } \\
\text { dengan baik? }\end{array}$} & $\mathrm{Ya}$ & 39 & 60,94 \\
\hline & Tidak & 25 & 39,06 \\
\hline & Total & 64 & 100,00 \\
\hline \multirow{3}{*}{$\begin{array}{l}\text { Saudara } \\
\text { menggunakan } \\
\text { bahasa daerah lain } \\
\text { selain bahasa } \\
\text { Tolaki? }\end{array}$} & $\mathrm{Ya}$ & 12 & 18,75 \\
\hline & Tidak & 52 & 81,25 \\
\hline & Total & 64 & 100,00 \\
\hline \multirow{3}{*}{$\begin{array}{l}\text { Saudara menguasai } \\
\text { bahasa asing? }\end{array}$} & $\mathrm{Ya}$ & 11 & 17,19 \\
\hline & Tidak & 53 & 82,81 \\
\hline & Total & 64 & 100,00 \\
\hline \multirow{3}{*}{$\begin{array}{l}\text { Penguasaan bahasa } \\
\text { Tolaki Saudara } \\
\text { lebih baik daripada } \\
\text { bahasa lain }\end{array}$} & $\mathrm{Ya}$ & 42 & 65,63 \\
\hline & Tidak & 22 & 34,38 \\
\hline & Total & 64 & 100,00 \\
\hline
\end{tabular}

Hampir semua masyarakat Tolaki yang tinggal di Kota Kendari dapat berbahasa Indonesia dengan baik. Bahkan, ada sebagian etnis Tolaki memiliki bahasa Indonesia sebagai bahasa ibu, walaupun mereka juga bisa berbahasa Tolaki yang mereka peroleh dari lingkungan sosial. Ada juga etnis Tolaki yang bisa menguasai bahasa daerah lain, dan ada juga yang bisa berbahasa asing. Berdasarkan tabel tersebut, tidak semua etnis Tolaki bisa berbahasa Tolaki dengan baik. Ada yang hanya tingkat penguasaannya dalam tahap pasif atau memahami saja tetapi tidak bisa mengucapkan. Ada juga yang memang sudah tidak tahu sama sekali bahasa Tolaki. Bahasa daerah lain yang biasa diketahui dan bahkan dikuasai oleh etnis Tolaki adalah bahasa Bugis. Bahasa Bugis secara psikologis lebih dekat 
dengan mereka dan biasanya lingkungan sosial mereka juga membiasakan mereka mendengar bahasa Bugis.

\section{Ranah Keluarga}

Penggunaan bahasa daerah di ranah keluarga menjadi faktor utama dalam penguasaan dan pewarisan bahasa daerah. Lingkungan keluarga menjadi ujung tombak tempat pewarisan bahasa daerah kepada anak-anak (generasi penerus). Usaha untuk melestarikan bahasa daerah akan sia-sia jika tidak dimulai dari lingkungan keluarga. Ranah keluarga merupakan pertahanan terakhir pemertahanan bahasa. Berikut ini jawaban responden dalam kaitannya dengan penggunaan bahasa Tolaki dalam ranah keluarga.

Tabel 5

Ranah Keluarga

\begin{tabular}{l|c|c|c}
\multicolumn{4}{c}{ Ranah Keluarga } \\
\hline \multicolumn{1}{c}{ Pertanyaan } & $\begin{array}{c}\text { Pilihan } \\
\text { Jawaban }\end{array}$ & $\mathbf{F}$ & $\mathbf{\%}$ \\
\hline $\begin{array}{l}\text { Saudara meng- } \\
\text { gunakan bahasa }\end{array}$ & Ya & 44 & 68,75 \\
\cline { 2 - 4 } $\begin{array}{l}\text { Tolaki jika berbicara } \\
\text { kepada yang lebih } \\
\text { tua dalam keluarga? }\end{array}$ & Total & $\mathbf{6 4}$ & $\mathbf{1 0 0 , 0 0}$ \\
\cline { 2 - 4 } $\begin{array}{l}\text { Saudara mengoreksi } \\
\text { kesalahan berbahasa }\end{array}$ & Ya & 18 & 28,13 \\
\cline { 2 - 4 } $\begin{array}{l}\text { Tolaki orang yang } \\
\text { lebih tua dalam }\end{array}$ & Tidak & 46 & 71,87 \\
\hline $\begin{array}{l}\text { keluarga? } \\
\text { Saudara mengoreksi }\end{array}$ & Ya & $\mathbf{6 4}$ & $\mathbf{1 0 0 , 0 0}$ \\
\cline { 2 - 4 } $\begin{array}{l}\text { kesalahan berbahasa } \\
\text { Tolaki orang yang }\end{array}$ & Tidak & 21 & 32,81 \\
\cline { 2 - 4 } $\begin{array}{l}\text { lebih muda dalam } \\
\text { keluarga? }\end{array}$ & Total & $\mathbf{6 4}$ & $\mathbf{1 0 0 , 0 0}$ \\
\hline $\begin{array}{l}\text { Saudara berbicara } \\
\text { menggunakan bahasa }\end{array}$ & Ya & 17 & 26,56 \\
\cline { 2 - 4 } $\begin{array}{l}\text { Tolaki jika berbicara } \\
\text { kepada orang yang }\end{array}$ & Total & $\mathbf{6 4}$ & $\mathbf{1 0 0 , 0 0}$ \\
$\begin{array}{l}\text { lebih muda dalam } \\
\text { keluarga? }\end{array}$ & Ya & 38 & 59,38 \\
\hline $\begin{array}{l}\text { Saudara berbicara } \\
\text { dengan anak } \\
\text { menggunakan } \\
\text { bahasa Tolaki? }\end{array}$ & Ya & 11 & 17,19 \\
\cline { 2 - 4 } $\begin{array}{l}\text { Saudara berbicara } \\
\text { dengan para orang } \\
\text { tua menggunakan } \\
\text { bahasa Tolaki? }\end{array}$ & Tidak & 53 & 82,81 \\
\cline { 2 - 4 } & Total & $\mathbf{6 4}$ & $\mathbf{1 0 0 , 0 0}$ \\
\cline { 2 - 4 } & Total & $\mathbf{6 4}$ & $\mathbf{1 0 0 , 0 0}$ \\
\hline
\end{tabular}

\begin{tabular}{l|c|c|c}
\hline Saudara & Ya & 34 & 51,13 \\
\cline { 2 - 4 } $\begin{array}{l}\text { mengajarkan bahasa } \\
\text { Tolaki kepada anak }\end{array}$ & Tidak & 30 & 48,87 \\
\cline { 2 - 4 } atau saudara? & Total & $\mathbf{6 4}$ & $\mathbf{1 0 0 , 0 0}$ \\
\hline $\begin{array}{l}\text { Saudara mengoreksi } \\
\text { kesalahan berbahasa } \\
\text { Tolaki pada anak } \\
\text { atau saudara? }\end{array}$ & Ya & 33 & 51,56 \\
\cline { 2 - 4 } & Tidak & 31 & 48,44 \\
\hline Orang tua dalam & Yatal & $\mathbf{6 4}$ & $\mathbf{1 0 0 , 0 0}$ \\
\cline { 2 - 4 } $\begin{array}{l}\text { suku Saudara } \\
\text { mengajarkan bahasa }\end{array}$ & Tidak & 10 & 15,62 \\
\cline { 2 - 4 } $\begin{array}{l}\text { Tolaki kepada anak- } \\
\text { anak mereka? }\end{array}$ & Total & $\mathbf{6 4}$ & $\mathbf{1 0 0 , 0 0}$ \\
\hline $\begin{array}{l}\text { Selain bahasa Tolaki, } \\
\text { Saudara mengguna- } \\
\text { kan bahasa lain } \\
\text { dalam keluarga? }\end{array}$ & Ya & 37 & 57,81 \\
\cline { 2 - 4 } & Tidak & 27 & 42,19 \\
\hline
\end{tabular}

Berdasarkan tabel tersebut dapat dijelaskan bahwa pewarisan bahasa Tolaki kepada anak atau anak-anak umumnya sudah jarang dilakukan. Hal tersebut dapat dilihat pada pertanyaan poin enam dan tujuh. Selain itu, walaupun rata-rata jawaban responden berada di atas 50\% tetapi posisi angka pada hampir setiap pertanyaan tidak terlalu dominan, khususnya untuk berbicara kepada yang lebih muda dan mengoreksi kesalahan.

Orang tua memiliki kewajiban untuk mengajar dan mendidik anak-anak mereka. Bukan hanya tata krama dan sopan santun melainkan juga budaya (termasuk bahasa). Upaya orang tua untuk mewariskan apa yang mereka miliki, khususnya pengetahuan, pasti terjadi pada setiap keluarga. Pewarisan bahasa oleh orang tua kepada anak adalah gerbang pertama yang harus dilewati dalam pelestarian bahasa daerah. Kalau sudah tidak ada pewarisan bahasa daerah dalam keluarga, kecil kemungkinan sebuah bahasa daerah akan bertahan hidup. Berdasarkan angka dalam tabel poin 9 bahwa orang tua umumnya masih berupaya mengajarkan dan mewariskan bahasa Tolaki kepada anak-anak mereka walaupun tantangannya sangat besar karena 
mereka hidup dalam budaya yang majemuk.

Sebagaimana kondisi kebahasaan di Indonesia, masyarakat Indonesia ratarata menguasai dua bahasa, bahasa daerah dan bahasa Indonesia. Adakalanya bahasa daerah yang jadi bahasa ibu dan ada juga sebagian memiliki bahasa ibu bahasa Indonesia. Kompleksitas situasi kebahasaan di Indonesia menjadi tantangan tersendiri dalam pelestarian bahasa daerah. Jika tidak ingin terkucilkan dari pergaulan antarsuku/etnis mau tidak mau harus menguasai bahasa Indonesia. Situasi inilah yang terjadi pada suku Tolaki di Kota Kendari. Masyarakat Tolaki harus memiliki kemampuan berbahasa Indonesia untuk berkomunikasi dengan suku lain yang ada di Kota Kendari. Apalagi jika sebuah keluarga suku Tolaki dikelilingi oleh etnis-etnis lain, mereka harus bisa berbahasa Indonesia untuk berkomunikasi dengan etnis lain. Ada juga kecenderungan terjadi pergeseran bahasa akibat interaksi secara intens dengan etnis lain.

\section{Ranah Antargenerasi dan Lingkungan}

Penggunaan bahasa Tolaki dalam ranah antargenerasi dan lingkungan dapat menjadi salah satu tolok ukur dalam pemertahanan bahasa. Jika bahasa daerah sudah tidak dipergunakan lagi dalam komunikasi sesama atau antargenerasi, hal tersebut dapat menjadi tanda-tanda kepunahan bahasa. Berikut ini dikemukakan jawaban dari responden mengenai hal tersebut.

Tabel 6

Ranah Antargenerasi dan Lingkungan

\begin{tabular}{l|c|c|c}
\hline \multicolumn{1}{c|}{ Pertanyaan } & $\begin{array}{c}\text { Pilihan } \\
\text { Jawaban }\end{array}$ & F & \% \\
\hline Saudara mengguna- & Ya & 40 & 62,50 \\
\cline { 2 - 4 } kan bahasa Tolaki & Tidak & 24 & 37,50 \\
\cline { 2 - 4 } jika berbicara & Total & $\mathbf{6 4}$ & $\mathbf{1 0 0 , 0 0}$ \\
\hline
\end{tabular}

\begin{tabular}{l|c|c|c}
\hline dengan orang tua? & & & \\
\hline $\begin{array}{l}\text { Saudara } \\
\text { menggunakan bahasa }\end{array}$ & Ya & 38 & 59,38 \\
\cline { 2 - 4 } $\begin{array}{l}\text { Tolaki jika berbicara } \\
\text { dengan keluarga? }\end{array}$ & 26 & 40,62 \\
\hline Saudara & Total & $\mathbf{6 4}$ & $\mathbf{1 0 0 , 0 0}$ \\
\cline { 2 - 4 } $\begin{array}{l}\text { menggunakan bahasa } \\
\text { Tolaki jika berbicara } \\
\text { dengan kerabat }\end{array}$ & Tidak & 33 & 48,44 \\
\cline { 2 - 4 } $\begin{array}{l}\text { Saudara yang lain? } \\
\text { Saudara }\end{array}$ & Total & $\mathbf{6 4}$ & $\mathbf{1 0 0 , 0 0}$ \\
\cline { 2 - 4 } $\begin{array}{l}\text { menggunakan bahasa } \\
\text { Tolaki jika berbicara } \\
\text { dengan anak }\end{array}$ & Tidak & 53 & 82,81 \\
\cline { 2 - 4 } $\begin{array}{l}\text { saudara/kemenakan? } \\
\text { Saudara }\end{array}$ & Total & $\mathbf{6 4}$ & $\mathbf{1 0 0 , 0 0}$ \\
\cline { 2 - 4 } $\begin{array}{l}\text { menggunakan bahasa } \\
\text { Tolaki jika }\end{array}$ & Tidak & 54 & 84,38 \\
\cline { 2 - 4 } $\begin{array}{l}\text { membicarakan } \\
\text { masalah sos-bud }\end{array}$ & Ta & 10 & 15,62 \\
\hline $\begin{array}{l}\text { dengan teman } \\
\text { sebaya? }\end{array}$ & Total & $\mathbf{6 4}$ & $\mathbf{1 0 0 , 0 0}$ \\
\hline $\begin{array}{l}\text { Saudara } \\
\text { menggunakan bahasa }\end{array}$ & Tidak & 46 & 71,18 \\
\cline { 2 - 4 } $\begin{array}{l}\text { Tolaki jika berbicara } \\
\text { dengan tetangga? }\end{array}$ & Total & $\mathbf{6 4}$ & $\mathbf{1 0 0 , 0 0}$ \\
\hline $\begin{array}{l}\text { Saudara } \\
\text { menggunakan bahasa }\end{array}$ & Tidak & 64 & 100,00 \\
\cline { 2 - 4 } $\begin{array}{l}\text { Tolaki jika berbicara } \\
\text { dengan tetangga dari } \\
\text { etnis lain? }\end{array}$ & Total & $\mathbf{6 4}$ & $\mathbf{1 0 0 , 0 0}$ \\
\hline & & 18 & 28,13 \\
\hline
\end{tabular}

Umumnya, masyarakat Tolaki jika berbicara dengan orang tua masih menggunakan bahasa Tolaki. Penggunaan bahasa Tolaki sebagai bentuk penghargaan dan penghormatan kepada orang tua. Namun, ada juga yang tidak menggunakan lagi bahasa Tolaki jika berbicara kepada orang tua. Biasanya, kondisi tersebut terjadi jika orang tersebut tidak aktif lagi menggunakan bahasa Tolaki (penutur pasif).

Penggunaan bahasa Tolaki dalam lingkungan keluarga dari berbagai lintas generasi semakin menunjukkan penurunan angka persentase, walaupun masih lebih banyak menggunakan bahasa Tolaki. Kenyataan tersebut menunjukkan bahwa dalam keluarga dari berbagai lintas generasi, bahasa Tolaki hanya dipergunakan dan ditujukan kepada orang-orang tua atau saudara 
yang lebih tua. Untuk yang satu generasi (seumur) atau generasi yang lebih muda cenderung digunakan bahasa Indonesia. Hal tersebut juga dapat dilihat pada komunikasi dengan kerabat saudara yang semakin memperlihatkan penurunan penggunaan bahasa Tolaki.

Dari tabel tersebut juga dapat dikemukakan bahwa semakin jauh hubungan keluarga dan jarak antargenerasi, penggunaan bahasa Tolaki dalam masyarakat etnis Tolaki juga semakin jarang dipergunakan. Penggunaan bahasa Tolaki dalam berkomunikasi dengan kemenakan, teman sebaya, dan tetangga sudah tidak dominan lagi digunakan oleh responden.

\section{Ranah Transaksi}

Ranah transaksi menjadi salah satu wilayah interaksi yang membutuhkan intensitas komunikasi yang tinggi. Tempat bertemunya berbagai masyarakat dari berbagai latar belakang budaya yang berbeda umumnya dapat dilihat di pasar. Berikut ini dikemukakan jawaban responden mengenai penggunaan bahasa Tolaki dalam ranah transaksi.

Tabel 7

Ranah Transaksi

\begin{tabular}{l|c|c|c}
\multicolumn{4}{c}{ Ranah Transaksi } \\
\hline \multirow{2}{*}{ Pertanyaan } & $\begin{array}{c}\text { Pilihan } \\
\text { Jawaban }\end{array}$ & F & \% \\
\hline $\begin{array}{l}\text { Saudara } \\
\text { menggunakan } \\
\text { bahasa Tolaki jika } \\
\text { berbelanja di pasar } \\
\text { di kampung? }\end{array}$ & Ya & 33 & 51,56 \\
\cline { 2 - 4 } & Total & 31 & 48,44 \\
\hline $\begin{array}{l}\text { Saudara } \\
\text { menggunakan } \\
\text { bahasa Tolaki jika } \\
\text { berbelanja di }\end{array}$ & Tidak & 59 & $\mathbf{1 0 0 , 0 0}$ \\
\cline { 2 - 4 } $\begin{array}{l}\text { warung atau } \\
\text { pedagang kelilng? }\end{array}$ & Total & $\mathbf{6 4}$ & $\mathbf{1 0 0 , 0 0}$ \\
\cline { 2 - 4 } $\begin{array}{l}\text { Saudara } \\
\text { menggunakan } \\
\text { bahasa Tolaki jika } \\
\text { berbelanja di } \\
\text { pasar di luar } \\
\text { kampung? }\end{array}$ & Yidak & 61 & 95,31 \\
\cline { 2 - 4 } & Total & $\mathbf{6 4}$ & $\mathbf{1 0 0 , 0 0}$ \\
\hline
\end{tabular}

\begin{tabular}{l|c|c|c}
\hline Saudara & Ya & 31 & 48,44 \\
\cline { 2 - 4 } $\begin{array}{l}\text { menggunakan } \\
\text { bahasa Tolaki jika } \\
\text { berbelanja di } \\
\text { pasar di luar } \\
\text { kampung yang } \\
\text { penjualnya }\end{array}$ & Tidak & 33 & 51,56 \\
\cline { 2 - 4 } seetnis? & Total & $\mathbf{6 4}$ & $\mathbf{1 0 0 , 0 0}$ \\
$\begin{array}{l}\text { Bahasa Tolaki } \\
\text { mudah digunakan } \\
\text { dalam } \\
\text { berinteraksi? }\end{array}$ & Ya & 9 & 14,06 \\
\cline { 2 - 4 } & Tidak & 55 & 85,94 \\
\hline
\end{tabular}

Dalam melakukan transaksi umumnya masyarakat Tolaki sudah banyak yang tidak menggunakan bahasa Tolaki. Aktivitas berbelanja di pasar kampung yang mayoritas berpenutur bahasa Tolaki tidak hanya didominasi oleh penggunaan bahasa Tolaki. Ada bahasa lain yang digunakan, yakni bahasa Indonesia. Patut dicermati bahwa masyarakat Tolaki sangat minim penguasaan dan pengusahaan dalam bidang ekonomi dan perdagangan. Menurut Taridala (2005), sentra-sentra kegiatan ekonomi di Kota Kendari pengelolanya bukan warga Tolaki. Termasuk juga para pedagang informal, seperti kaki lima dan asongan, dan pemilik jasa transportasi informal (ojek) sebagian besar di antaranya adalah juga bukan dari etnis Tolaki. Jadi, berdasarkan kenyataan tersebut interaksi yang terjadi dalan ranah transaksi adalah dilakukan oleh dua etnis yang berbeda, etnis Tolaki dan etnis lain. Hal tersebut menyebabkan bahasa Tolaki menjadi sulit untuk digunakan dalam bertransaksi karena adanya perbedaan bahasa antara pembeli dan penjual. Oleh karena itu, bahasa yang dipakai untuk berkomunikasi tentunya jatuh kepada bahasa Indonesia. Bahasa Tolaki digunakan pada ranah transaksi jika pembeli dari etnis Tolaki sudah mengenal dengan baik dan sudah menjadi langganan bahwa penjual yang dihadapi beretnis Tolaki. 


\section{Ranah Ekspresi Tulis}

Ekspresi tulis berkaitan dengan penggunaan bahasa pada ruang-ruang yang biasa menggunakan media tulis. Seiring perkembangan teknologi, bahasa tulis juga mengalami peningkatan fungsi. Bukan hanya digunakan pada suratmenyurat, pengumuman tertulis, dan lain-lain, melainkan juga digunakan untuk berkomunikasi tertulis dengan menggunakan teknologi canggih seperti ponsel dan komputer. Pengiriman pesan melalui SMS dan media sosial menjadi lazim untuk sekarang ini. Bahkan, ada pengembangan teknologi penulisan untuk beberapa bahasa daerah tertentu yang dapat menggunakan aplikasi khusus dalam melakukan interaksi tertulis dengan komputer atau melalui media sosial.

Tabel di bawah ini memperlihatkan jawaban responden dalam kaitannya penggunaan bahasa Tolaki dalam ranah ekspresi tulis.

Tabel 8

Ranah Ekspresi Tulis

\begin{tabular}{|c|c|c|c|}
\hline Pertanyaan & $\begin{array}{c}\text { Pilihan } \\
\text { Jawaban }\end{array}$ & $\mathbf{F}$ & $\%$ \\
\hline \multirow{3}{*}{$\begin{array}{l}\text { Saudara } \\
\text { menggunakan } \\
\text { bahasa Tolaki jika } \\
\text { menulis surat/sms } \\
\text { kepada keluarga? }\end{array}$} & $\mathrm{Ya}$ & 17 & 26,56 \\
\hline & Tidak & 47 & 73,44 \\
\hline & Total & 64 & 100,00 \\
\hline \multirow{3}{*}{$\begin{array}{l}\text { Saudara } \\
\text { menggunakan } \\
\text { bahasa Tolaki jika } \\
\text { menulis surat/sms } \\
\text { kepada teman? }\end{array}$} & $\mathrm{Ya}$ & 7 & 10,94 \\
\hline & Tidak & 56 & 89,06 \\
\hline & Total & 64 & 100,00 \\
\hline \multirow{3}{*}{$\begin{array}{l}\text { Saudara } \\
\text { menggunakan } \\
\text { bahasa Tolaki jika } \\
\text { menulis surat/sms } \\
\text { kepada } \\
\text { tokoh/pemuka } \\
\text { masyarakat Tolaki? }\end{array}$} & $\mathrm{Ya}$ & 21 & 32,81 \\
\hline & Tidak & 43 & 67,19 \\
\hline & Total & 64 & 100,00 \\
\hline \multirow{3}{*}{$\begin{array}{l}\text { Bahasa Tolaki dapat } \\
\text { dituliskan melalui } \\
\text { penggunaan } \\
\text { komputer tanpa } \\
\text { kendala teknis? } \\
\end{array}$} & $\mathrm{Ya}$ & 30 & 46,88 \\
\hline & Tidak & 34 & 53,13 \\
\hline & Total & 64 & 100,00 \\
\hline
\end{tabular}

Menurut responden bahwa bahasa Tolaki dalam ranah ekspresi tulis umumnya tidak digunakan. Salah satu alasan yang menyebabkan bahasa Tolaki tidak digunakan dalam ekspresi tulis, khususnya dengan menggunakan teknologi komunikasi, adalah membutuhkan penulisan kata yang lebih panjang. Berbeda dengan bahasa Indonesia, beberapa kata yang disingkat sudah dipahami dan dimengerti oleh penerima.Sementara, penyingkatan kosakata bahasa Tolaki belum ada kesepahaman dan kesepakatan antarpenutur. Penyingkatan kata tersebut kemungkinan bisa menyebabkan terjadinya kesalahpahaman. Jadi, penutur bahasa Tolaki masih lebih memilih menggunakan bahasa Indonesia dalam berkomunikasi secara tertulis.

Penggunaan bahasa Tolaki dalam aplikasi komputer, menurut sebagian besar responden, masih akan menghadapi kendala teknis. Untuk tujuan tersebut masih membutuhkan pengembangan teknologi dan kajian yang mendalam.

\section{Ranah Ekspresi Perasaan}

Ekspresi perasaan menjadi salah satu ranah penggunaan bahasa daerah. Penggunaan bahasa dalam ranah ini biasanya lebih spontan. Jika seseorang memiliki penguasaan bahasa daerah yang baik, pengungkapan perasaan secara spontan akan diekspresikan dalam bahasa daerah, khususnya dalam situasi sedang marah. Berikut ini dikemukakan jawaban responden mengenai penggunaan bahasa daerah dalam kaitannya dengan eksrepsi perasaan.

Tabel 9

Ranah Ekspresi Perasaan

\begin{tabular}{l|c|c|c}
\hline \multicolumn{1}{c|}{ Pertanyaan } & $\begin{array}{c}\text { Pilihan } \\
\text { Jawaban }\end{array}$ & $\mathbf{F}$ & $\mathbf{\%}$ \\
\hline $\begin{array}{l}\text { Saudara mengguna- } \\
\text { kan bahasa Tolaki }\end{array}$ & Ya & 22 & 34,38 \\
\cline { 2 - 4 } & Tidak & 42 & 65,62 \\
\hline
\end{tabular}




\begin{tabular}{l|c|c|c}
\hline jika marah kepada & Total & $\mathbf{6 4}$ & $\mathbf{1 0 0 , 0 0}$ \\
\hline $\begin{array}{l}\text { yang lebih tua? } \\
\text { Saudara }\end{array}$ & Ya & 21 & 32,81 \\
\cline { 2 - 4 } $\begin{array}{l}\text { menggunakan } \\
\text { bahasa Tolaki jika } \\
\text { marah kepada yang }\end{array}$ & Tidak & 45 & 67,19 \\
\cline { 2 - 4 } $\begin{array}{l}\text { lebih muda? } \\
\text { Saudara mengguna- }\end{array}$ & Total & $\mathbf{6 4}$ & $\mathbf{1 0 0 , 0 0}$ \\
\cline { 2 - 4 } $\begin{array}{l}\text { kan bahasa Tolaki } \\
\text { jika marah kepada }\end{array}$ & Tidak & 19 & 29,69 \\
\cline { 2 - 4 } $\begin{array}{l}\text { anak-anak? } \\
\text { Saudara }\end{array}$ & Total & $\mathbf{6 4}$ & $\mathbf{1 0 0 , 0 0}$ \\
\cline { 2 - 4 } $\begin{array}{l}\text { menggunakan } \\
\text { bahasa Tolaki jika } \\
\text { bertengkar dengan }\end{array}$ & Yidak & 21 & 32,81 \\
\cline { 2 - 4 } yang sebaya? & Total & $\mathbf{6 4}$ & $\mathbf{1 0 0 , 0 0}$ \\
\hline
\end{tabular}

Dari jawaban tersebut terlihat bahwa umumnya dalam mengekspresikan perasaan, responden cenderung tidak menggunakan bahasa Tolaki. Bahasa Indonesia masih menjadi pilihan utama dalam mengekspresikan perasaan. Hal tersebut menandakan bahwa umumnya responden memiliki penguasaan bahasa Tolaki yang kurang baik. Bahasa Tolaki yang dikuasai adalah bahasa yang hanya untuk keperluan komunikasi sehari-hari.

\section{Ranah Agama dan Adat}

Penggunaan bahasa daerah ranah agama/adat meliputi penggunaan bahasa oleh pemuka agama dan adat saat menjalankan aktivitas keagamaan dan adat. Ranah ini seharusnya menjadi wilayah yang tidak boleh lepas dari penggunaan bahasa daerah. Jika dalam ranah ini para pemangku adat/agama tidak menggunakan bahasa daerah, dapat menjadi gejala menuju kepunahan bahasa.Seharusnya wilayah ini menjadi salah satu wadah dalam pengenalan dan pewarisan bahasa daerah kepada masyarakat penuturnya.

\section{Tabel 10}

Ranah Agama dan Adat

\begin{tabular}{l|c|c|c}
\hline \multicolumn{1}{c}{ Pertanyaan } & $\begin{array}{c}\text { Pilihan } \\
\text { Jawaban }\end{array}$ & F & $\mathbf{\%}$ \\
\hline $\begin{array}{l}\text { Pemuka agama } \\
\text { menggunakan }\end{array}$ & Ya & 12 & 18,75 \\
\cline { 2 - 4 } & Tidak & 52 & 81,25 \\
\hline
\end{tabular}

\begin{tabular}{|c|c|c|c|}
\hline $\begin{array}{l}\text { bahasa Tolaki jika ia } \\
\text { berkhotbah di } \\
\text { masjid/gereja? }\end{array}$ & Total & 64 & 100,00 \\
\hline \multirow{3}{*}{$\begin{array}{l}\text { Pemuka agama } \\
\text { menggunakan } \\
\text { bahasa Tolaki jika ia } \\
\text { ada dalam upacara } \\
\text { perkawinan? }\end{array}$} & $\mathrm{Ya}$ & 60 & 9,75 \\
\hline & Tidak & 4 & 6,25 \\
\hline & Total & 64 & 100,00 \\
\hline \multirow{3}{*}{$\begin{array}{l}\text { Pemuka agama } \\
\text { menggunakan } \\
\text { bahasa Tolaki jika } \\
\text { ada upacara } \\
\text { kematian? }\end{array}$} & $\mathrm{Ya}$ & 36 & 56,25 \\
\hline & Tidak & 28 & 43,75 \\
\hline & Total & 64 & 100,00 \\
\hline \multirow{3}{*}{$\begin{array}{l}\text { Pemuka agama } \\
\text { menggunakan } \\
\text { bahasa Tolaki jika } \\
\text { ada upacara } \\
\text { kelahiran? }\end{array}$} & $\mathrm{Ya}$ & 31 & 48,44 \\
\hline & Tidak & 33 & 51,56 \\
\hline & Total & 64 & 100,00 \\
\hline \multirow{3}{*}{$\begin{array}{l}\text { Saudara } \\
\text { menggunakan } \\
\text { bahasa Tolaki jika } \\
\text { berdoa? }\end{array}$} & $\mathrm{Ya}$ & 6 & 9,38 \\
\hline & Tidak & 58 & 90,62 \\
\hline & Total & 64 & 100,00 \\
\hline
\end{tabular}

responden bahwa dalam khotbah, bahasa Tolaki hampir tidak pernah digunakan. Alasan tidak digunakan bahasa Tolaki karena pendengar khotbah berasal dari berbagai etnis. Khotbah yang menggunakan bahasa Tolaki atau diselingi dengan bahasa Tolaki bisa menyebabkan jamaah tidak mengerti maksud pengkhotbah. Namun, pada kesempatan lain, ada beberapa pengkhotbah justru biasa menyelipkan bahasa daerah yang bukan bahasa Tolaki pada beberapa khotbahnya.

Pada acara adat seperti upacara perkawinan etnis Tolaki, bahasa Tolaki masih menjadi pilihan utama. Namun, pada situasi pernikahan yang berbeda etnis, seperti pernikahan etnis Tolaki dan etnis lain, pilihan penggunaan bahasa bisa disesuaikan dengan situasi yang ada. Terkadang bahasa Tolaki tidak dipergunakan, cenderung digunakan bahasa Indonesia. Sementara itu, pada upacara kematian atau kelahiran, yang menggunakan bahasa Tolaki dan yang tidak menggunakan cenderung berimbang. Artinya, ada yang menggunakan bahasa Tolaki dan ada 
juga yang tidak menggunakan lagi. Berbeda halnya pada saat berdoa. Hampir semua responden jika berdoa tidak menggunakan bahasa Tolaki.

\section{Ranah Pemerintahan dan Lembaga Swasta}

Penggunaan bahasa Tolaki dalam ranah pemerintahan dan lembaga swasta meliputi pengumuman, pelayanan, penulisan surat dinas, dan pelindungan bahasa Tolaki oleh pemerintah setempat. Indikator ini berusaha melihat sejauh mana peran dan kepedulian pemerintah dan lembaga swasta dalam melestarikan bahasa daerah berdasarkan pandangan responden.

Tabel 11

Ranah Pemerintahan dan Lembaga Swasta

\begin{tabular}{|c|c|c|c|}
\hline Pertanyaan & $\begin{array}{c}\text { Pilihan } \\
\text { Jawaban }\end{array}$ & $\mathbf{F}$ & $\%$ \\
\hline \multirow{3}{*}{$\begin{array}{l}\text { Saudara mudah } \\
\text { memahami } \\
\text { pengumuman jika } \\
\text { ditulis dalam bahasa } \\
\text { Tolaki? }\end{array}$} & $\mathrm{Ya}$ & 49 & 76,56 \\
\hline & Tidak & 15 & 23,44 \\
\hline & Total & 64 & 100,00 \\
\hline \multirow{3}{*}{$\begin{array}{l}\text { Saudara } \\
\text { menggunakan } \\
\text { bahasa Tolaki jika } \\
\text { mengurus kartu } \\
\text { penduduk atau } \\
\text { meminta surat } \\
\text { keterangan di kantor } \\
\text { kelurahan? }\end{array}$} & $\mathrm{Ya}$ & 3 & 4,69 \\
\hline & Tidak & 61 & 95,31 \\
\hline & Total & 64 & 100,00 \\
\hline \multirow{3}{*}{$\begin{array}{l}\text { Bahasa Tolaki } \\
\text { digunakan oleh } \\
\text { aparat kecamatan } \\
\text { atau kelurahan } \\
\text { ketika berbicara } \\
\text { dengan orang-orang } \\
\text { dari suku Tolaki? }\end{array}$} & $\mathrm{Ya}$ & 37 & 57,81 \\
\hline & Tidak & 27 & 42,19 \\
\hline & Total & 64 & 100,00 \\
\hline \multirow{3}{*}{$\begin{array}{l}\text { Saudara } \\
\text { menggunakan } \\
\text { bahasa Tolaki jika } \\
\text { berobat? }\end{array}$} & $\mathrm{Ya}$ & 2 & 3,13 \\
\hline & Tidak & 62 & 96,88 \\
\hline & Total & 64 & 100,00 \\
\hline \multirow{3}{*}{$\begin{array}{l}\text { Saudara memahami } \\
\text { isi pengumuman } \\
\text { dala bahasa Tolaki } \\
\text { yang disampaikan } \\
\text { aparat pemerintah? }\end{array}$} & $\mathrm{Ya}$ & 51 & 79,69 \\
\hline & Tidak & 13 & 20,31 \\
\hline & Total & 64 & 100,00 \\
\hline \multirow{2}{*}{$\begin{array}{l}\text { Ada kewajiban } \\
\text { penggunaan bahasa }\end{array}$} & $\mathrm{Ya}$ & 8 & 12,50 \\
\hline & Tidak & 56 & 87,50 \\
\hline
\end{tabular}

\begin{tabular}{|c|c|c|c|}
\hline $\begin{array}{l}\text { Tolaki dalam ranah } \\
\text { pemerintahan pada } \\
\text { hari tertentu? }\end{array}$ & Total & 64 & 100,00 \\
\hline \multirow{3}{*}{$\begin{array}{l}\text { Bahasa Tolaki } \\
\text { digunakan dalam } \\
\text { surat-surat yang } \\
\text { ditulis pemerintah } \\
\text { untuk warga suku } \\
\text { Tolaki? }\end{array}$} & $\mathrm{Ya}$ & 7 & 11,11 \\
\hline & Tidak & 56 & 88,89 \\
\hline & Total & 64 & 100,00 \\
\hline \multirow{3}{*}{$\begin{array}{l}\text { Bahasa Tolaki } \\
\text { dianjurkan oleh oleh } \\
\text { pemerintah daerah? }\end{array}$} & $\mathrm{Ya}$ & 18 & 28,12 \\
\hline & Tidak & 46 & 71,88 \\
\hline & Total & 64 & 100,00 \\
\hline \multirow{3}{*}{$\begin{array}{l}\text { Bahasa Tolaki wajib } \\
\text { digunakan dalam } \\
\text { layanan publik pada } \\
\text { hari tertentu? }\end{array}$} & $\mathrm{Ya}$ & 6 & 9,38 \\
\hline & Tidak & 58 & 90.62 \\
\hline & Total & 64 & 100,00 \\
\hline \multirow{3}{*}{$\begin{array}{l}\text { Pemerintah daerah } \\
\text { menghargai } \\
\text { penggunaan bahasa } \\
\text { Tolaki? }\end{array}$} & $\mathrm{Ya}$ & 59 & 92,19 \\
\hline & Tidak & 5 & $, 7,81$ \\
\hline & Total & 64 & 100,00 \\
\hline \multirow{3}{*}{$\begin{array}{l}\text { Pemerintah daerah } \\
\text { mengembangkan } \\
\text { dan melindungi } \\
\text { bahasa Tolaki? }\end{array}$} & $\mathrm{Ya}$ & 56 & 87,50 \\
\hline & Tidak & 8 & 12,50 \\
\hline & Total & 64 & 100,00 \\
\hline \multirow{3}{*}{$\begin{array}{l}\text { Lembaga adat } \\
\text { menganjurkan agar } \\
\text { bahasa Tolaki tetap } \\
\text { digunakan? }\end{array}$} & $\mathrm{Ya}$ & 58 & 90,63 \\
\hline & Tidak & 6 & 9,38 \\
\hline & Total & 64 & 100,00 \\
\hline \multirow{3}{*}{$\begin{array}{l}\text { Lembaga adat } \\
\text { melindungi bahasa } \\
\text { Tolaki dengan baik? }\end{array}$} & $\mathrm{Ya}$ & 57 & 89,06 \\
\hline & Tidak & 7 & 10,94 \\
\hline & Total & 64 & 100,00 \\
\hline \multirow{3}{*}{$\begin{array}{l}\text { Perusahaan swasta } \\
\text { mengizinkan } \\
\text { penggunaan bahasa } \\
\text { Tolaki? }\end{array}$} & $\mathrm{Ya}$ & 12 & 18,75 \\
\hline & Tidak & 52 & 81,25 \\
\hline & Total & 64 & 100,00 \\
\hline \multirow{3}{*}{$\begin{array}{l}\text { Bahasa Tolaki } \\
\text { digunakan untuk } \\
\text { menulis perjanjian } \\
\text { sewa-menyewa atau } \\
\text { jual beli? }\end{array}$} & $\mathrm{Ya}$ & 5 & 7,81 \\
\hline & Tidak & 59 & 92,19 \\
\hline & Total & 64 & 100,00 \\
\hline
\end{tabular}

Bagi penutur bahasa Tolaki, pengumuman yang disampaikan secara tertulis dan lisan umumnya masih dapat dipahami dan dimengerti. Dalam pelayanan kepada masyarakat umumnya bahasa Tolaki tidak dipergunakan. Hal tersebut disebabkan karena yang dilayani adalah masyarakat dari berbagai etnis. Kemajemukan etnis menjadikan bahasa Tolaki tidak menjadi bahasa pengantar utama dalam pelayanan kepada masyarakat, khususnya di puskesmas. Berbeda halnya jika yang dilayani adalah orang yang dikenal sebagai satu suku, 
bahasa Tolaki masih dipergunakan. Penggunaan bahasa Tolaki pada harihari tertentu berdasarkan peraturan dan anjuran dari Pemerintah Kota Kendari belum ada. Hal tersebut dalam beberapa tahun belakangan hanya menjadi wacana tetapi tidak pernah dilaksanakan.

Berdasarkan jawaban pada tabel di atas, ada anggapan yang optimis dari para responden bahwa pemerintah Kota Kendari dan lembaga adat dapat mengembangkan, melindungi, menganjurkan penggunaan bahasa Tolaki. Walaupun secara konkret usaha tersebut belum pernah ada penerapannya, masyarakat Tolaki di Kota Kendari masih memercayai pengembangan, pelindungan, penggunaan secara luas bahasa Tolaki dapat dilakukan oleh pemerintah.

Pada sisi lain, umumnya responden menganggap bahwa pihak swasta kurang memberikan perhatian terhadap keberlangsungan bahasa Tolaki. Perlu dipahami bahwa pihak swasta tentunya dalam menjalankan usahanya berorientasi pada hasil. Jika ada sesuatu yang dianggap menjadi penghambat datangnya keuntungan, hal itu akan dihindari dan diminimalkan.

\section{Ranah Pendidikan}

Variabel ranah pendidikan meliputi penggunaan bahasa Tolaki dalam proses belajar-mengajar dan di lingkungan sekolah. Ranah pendidikan menjadi tempat bertemu dan berbaurnya beberapa budaya yang dibawa oleh masing-masing perserta didik. Pada situasi dan lingkungan yang homogeny, situasi kebahasaan tidak akan terlalu kompleks. Berbeda jika situasi dan lingkungannya heterogen, di sinilah akan terjadi pemerolehan bahasa baru dan pengaruh bahasa daerah lain pada peserta didik. Pengenalan dan pemerolehan satu atau beberapa kata bisa terjadi pada lingkungan sekolah yang lingkungannya heterogen. Untuk kasus di Kota Kendari, pengaruh bahasa daerah itu bisa berasal dari bahasa Tolaki, atau bahasa daerah lain yang mayoritas seperti bahasa Bugis atau bahasa Muna.

Tabel 12

Ranah Pendidikan

\begin{tabular}{|c|c|c|c|}
\hline Pertanyaan & $\begin{array}{c}\text { Pilihan } \\
\text { Jawaban }\end{array}$ & $\mathbf{F}$ & $\%$ \\
\hline \multirow{3}{*}{$\begin{array}{l}\text { Saudara setuju } \\
\text { bahasa Tolaki } \\
\text { diajarkan di } \\
\text { sekolah-sekolah di } \\
\text { Kendari? }\end{array}$} & $\mathrm{Ya}$ & 59 & 92,19 \\
\hline & Tidak & 5 & 7,81 \\
\hline & Total & 64 & 100,00 \\
\hline \multirow{3}{*}{$\begin{array}{l}\text { Saudara setuju jika } \\
\text { di sekolah guru } \\
\text { menggunakan } \\
\text { bahasa Tolaki } \\
\text { ketika mengajar? }\end{array}$} & $\mathrm{Ya}$ & 9 & 14,06 \\
\hline & Tidak & 55 & 85,94 \\
\hline & Total & 64 & 100,00 \\
\hline \multirow{3}{*}{$\begin{array}{l}\text { Saudara setuju jika } \\
\text { di luar kelas guru } \\
\text { dan murid } \\
\text { menggunakan } \\
\text { bahasa Tolaki? }\end{array}$} & $\mathrm{Ya}$ & 36 & 56,25 \\
\hline & Tidak & 28 & 43,75 \\
\hline & Total & 64 & 100,00 \\
\hline \multirow{3}{*}{$\begin{array}{l}\text { Saudara setuju jika } \\
\text { di luar kelas guru } \\
\text { sesama etnis Tolaki } \\
\text { menggunakan } \\
\text { bahasa Tolaki? }\end{array}$} & $\mathrm{Ya}$ & 58 & 90,63 \\
\hline & Tidak & 6 & 9,38 \\
\hline & Total & 64 & 100,00 \\
\hline \multirow{3}{*}{$\begin{array}{l}\text { Saudara setuju jika } \\
\text { di luar kelas murid } \\
\text { sesama etnis } \\
\text { Tolaki mengguna- } \\
\text { kan bahasa Tolaki? }\end{array}$} & $\mathrm{Ya}$ & 53 & 82,81 \\
\hline & Tidak & 11 & 17,19 \\
\hline & Total & 64 & 100,00 \\
\hline \multirow{3}{*}{$\begin{array}{l}\text { Saudara setuju jika } \\
\text { di luar kelas murid } \\
\text { yang tidak seetnis } \\
\text { menggunakan } \\
\text { bahasa Tolaki? }\end{array}$} & $\mathrm{Ya}$ & 19 & 29,69 \\
\hline & Tidak & 45 & 70,31 \\
\hline & Total & 64 & 100,00 \\
\hline \multirow{3}{*}{$\begin{array}{l}\text { Bahasa Tolaki } \\
\text { dapat digunakan } \\
\text { untuk } \\
\text { mendiskusikan } \\
\text { ilmu pengetahuan } \\
\text { modern? }\end{array}$} & $\mathrm{Ya}$ & 42 & 65,63 \\
\hline & Tidak & 22 & 34,38 \\
\hline & Total & 64 & 100,00 \\
\hline \multirow{3}{*}{$\begin{array}{l}\text { Banyak buku } \\
\text { sekolah ditulis } \\
\text { dalam bahasa } \\
\text { Tolaki? }\end{array}$} & $\mathrm{Ya}$ & 9 & 14,06 \\
\hline & Tidak & 55 & 85,94 \\
\hline & Total & 64 & 100,00 \\
\hline
\end{tabular}

Berdasarkan tabel tersebut dapat dikemukakan bahwa mayoritas responden menginginkan bahasa Tolaki 
diajarkan di sekolah. Begitu juga dalam komunikasi bagi guru dan murid yang sesama etnis Tolaki, umumnya responden menghendaki digunakan bahasa Tolaki. Namun, dalam kenyataannya ada sebagian guru yang beretnis Tolaki jika bertemu dengan guru sesama etnis Tolaki tidak lagi menggunakan bahasa Tolaki sebagai alat komunikasi. Mereka cenderung menggunakan bahasa Indonesia. Apalagi dengan murid dari etnis Tolaki yang kemampuan bahasa Tolakinya sangat kurang atau bahkan hanya sebagai penutur pasif pastinya tidak akan menggunakan bahasa Tolaki jika bertemu dengan teman sesama dari etnis.

Hal lain yang perlu dikemukakan adalah responden umumnya tidak menyetujui jika bahasa Tolaki digunakan dalam proses belajar-mengajar, bahkan sebagai bahasa pengantar sekali pun. Termasuk juga penggunaan bahasa Tolaki bagi murid etnis Tolaki ke etnis lain. Responden menyadari bahwa di Kota Kendari telah dihuni oleh berbagai etnis, termasuk dalam lingkungan sekolah. Tidak ada etnis yang mayoritas dalam sebuah sekolah di Kendari. Semua berbaur sebagai warga Kendari. Umumnya, siswa hanya mengetahui keetnisannya, tetapi tidak bisa lagi menuturkan bahasa dari etnis mereka.

Menurut responden, belum banyak buku yang ditulis dalam bahasa Tolaki. Kebanyakan adalah buku yang membahas mengenai etnis Tolaki termasuk daerahnya. Buku yang berbahasa Tolaki hanya kita temui dalam buku pegangan pembelajaran muatan lokal, itu pun biasanya disertai dan diselingi dengan penjelasan dalam bahasa Indonesia.

\section{Ranah Dokumentasi dan Media Massa}

Dokumentasi berkaitan dengan jenis, kuantitas, dan kualitas yang ada dalam suatu masyarakat tutur. Dokumentasi kebahasaan penting karena berbagai alasan sebagai berikut: 1) memperkaya kekayaan intelektual manusia; 2) menyajikan perspektif budaya yang baru bagi pengetahuan saat ini; dan 3) membantu untuk mengaktifkan kembali pengetahuan linguistik dan budaya. Dokumentasi yang paling penting adalah teks tertulis termasuk rekaman audio visual yang diterjemahkan dan beranotasi dari percakapan alami.

Bahasa Tolaki termasuk bahasa yang jenis dan kualitas dokumentasinya masih belum memadai dari segi kuantitas. Beberapa buku yang menulis mengenai budaya dan masyarakat etnis Tolaki sudah ada.

Tabel 13

Ranah Dokumentasi dan Media Massa

\begin{tabular}{|c|c|c|c|}
\hline Pertanyaan & $\begin{array}{c}\text { Pilihan } \\
\text { Jawaban }\end{array}$ & $\mathbf{F}$ & $\%$ \\
\hline \multirow{3}{*}{$\begin{array}{l}\text { Bahasa Tolaki } \\
\text { memiliki sistem } \\
\text { aksara. }\end{array}$} & $\mathrm{Ya}$ & 35 & 54,69 \\
\hline & Tidak & 29 & 45,31 \\
\hline & Total & 64 & 100,00 \\
\hline \multirow{3}{*}{$\begin{array}{l}\text { Dokumentasi } \\
\text { tentang bahasa } \\
\text { Tolaki dapat } \\
\text { ditemukan secara } \\
\text { mudah. }\end{array}$} & $\mathrm{Ya}$ & 35 & 54,69 \\
\hline & Tidak & 29 & 45,31 \\
\hline & Total & 64 & 100,00 \\
\hline \multirow{3}{*}{$\begin{array}{l}\text { Dokumentasi } \\
\text { tentang bahasa } \\
\text { Tolaki disusun } \\
\text { dalam bentuk buku. }\end{array}$} & $\mathrm{Ya}$ & 43 & 67,19 \\
\hline & Tidak & 21 & 32,81 \\
\hline & Total & 64 & 100,00 \\
\hline \multirow{3}{*}{$\begin{array}{l}\text { Dokumentasi } \\
\text { tentang bahasa } \\
\text { Tolaki sudah } \\
\text { ditemukan sejak } \\
\text { abad yang lalu. }\end{array}$} & $\mathrm{Ya}$ & 45 & 70,31 \\
\hline & Tidak & 19 & 29,69 \\
\hline & Total & 64 & 100,00 \\
\hline \multirow{3}{*}{$\begin{array}{l}\text { Sudah banyak } \\
\text { tulisan dalam } \\
\text { bahasa Tolaki. }\end{array}$} & $\mathrm{Ya}$ & 43 & 67,19 \\
\hline & Tidak & 21 & 32,81 \\
\hline & Total & 64 & 100,00 \\
\hline \multirow{3}{*}{$\begin{array}{l}\text { Dapat juga ditemu- } \\
\text { kan rekaman suara } \\
\text { dalam bahasa } \\
\text { Tolaki }\end{array}$} & $\mathrm{Ya}$ & 34 & 53,13 \\
\hline & Tidak & 30 & 46,88 \\
\hline & Total & 64 & 100,00 \\
\hline \multirow{3}{*}{$\begin{array}{l}\text { Sudah ada } \\
\text { dokumentasi } \\
\text { tentang sejarah } \\
\text { bahasa Tolaki. }\end{array}$} & $\mathrm{Ya}$ & 54 & 84 \\
\hline & Tidak & 10 & 38 \\
\hline & Total & 64 & 100,00 \\
\hline \multirow{2}{*}{$\begin{array}{l}\text { Ada bahan ajar } \\
\text { yang memadai }\end{array}$} & $\mathrm{Ya}$ & 44 & 68,75 \\
\hline & Tidak & 20 & 31,25 \\
\hline
\end{tabular}




\begin{tabular}{|c|c|c|c|}
\hline $\begin{array}{l}\text { untuk pembelajaran } \\
\text { bahasa Tolaki. }\end{array}$ & Total & 64 & 100,00 \\
\hline \multirow{3}{*}{$\begin{array}{l}\text { Kamus bahasa } \\
\text { Tolaki telah } \\
\text { disusun. }\end{array}$} & $\mathrm{Ya}$ & 35 & 54 \\
\hline & Tidak & 29 & 69 \\
\hline & Total & 64 & 100,00 \\
\hline \multirow{3}{*}{$\begin{array}{l}\text { Bahasa Tolaki } \\
\text { didokumentasikan } \\
\text { dengan baik. }\end{array}$} & $\mathrm{Ya}$ & 34 & 53,13 \\
\hline & Tidak & 30 & 46,88 \\
\hline & Total & 64 & 100,00 \\
\hline \multirow{3}{*}{$\begin{array}{l}\text { Banyak bahan } \\
\text { bacaan dalam } \\
\text { bahasa Tolaki. }\end{array}$} & $\mathrm{Ya}$ & 29 & 45,31 \\
\hline & Tidak & 35 & 54,69 \\
\hline & Total & 64 & 100,00 \\
\hline \multirow{3}{*}{$\begin{array}{l}\text { Penutur bahasa } \\
\text { Tolaki menyukai } \\
\text { siaran radio } \\
\text { berbahasa lain. }\end{array}$} & $\mathrm{Ya}$ & 40 & 62,50 \\
\hline & Tidak & 24 & 37,50 \\
\hline & Total & 64 & 100,00 \\
\hline \multirow{3}{*}{$\begin{array}{l}\text { Banyak orang yang } \\
\text { bisa diajak } \\
\text { berkomunikasi } \\
\text { dengan bahasa } \\
\text { Tolaki di internet. }\end{array}$} & $\mathrm{Ya}$ & 21 & 32,81 \\
\hline & Tidak & 43 & 67,19 \\
\hline & Total & 64 & 100,00 \\
\hline \multirow{3}{*}{$\begin{array}{l}\text { Berita dalam media } \\
\text { massa perlu } \\
\text { disajikan dalam } \\
\text { bahasa Tolaki } \\
\end{array}$} & $\mathrm{Ya}$ & 25 & 39,06 \\
\hline & Tidak & 39 & 60,94 \\
\hline & Total & 64 & 100,00 \\
\hline
\end{tabular}

Menurut sebagian reponden bahwa bahasa Tolaki memiliki sistem aksara. Namun, pada kenyataannya bahasa Tolaki selalu dituliskan dalam aksara Latin. Sistem aksara yang dimaksud belum pernah muncul ke permukaan atau tidak pernah digunakan. Pengenalan aksara Tolaki di dalam ranah pendidikan tidak pernah ada. Responden yang menjawab bahasa Tolaki memiliki sistem aksara hanya pernah mendengar saja tetapi tidak pernah melihat secara langsung aksara tersebut.

Berkaitan dengan tabel tersebut juga dapat dikemukakan bahwa jawaban responden mengenai dokumentasi bahasa Tolaki tidak ada yang terlalu dominan yang mengatakan ada dan tidak ada. Hal tersebut disebabkan karena sebagian dokumentasi mengenai bahasa Tolaki tidak tersebar merata di dalam masyarakat Tolaki. Dokumentasi mengenai bahasa Tolaki biasanya hanya diketahui oleh orang yang berkepentingan dengan bahasa Tolaki, seperti peneliti, mahasiswa, guru, dan pihak pemerintah. Selama ini juga bahan dokumentasi tersebut dibuat oleh pihak pemerintah sebagai upaya pelestarian bahasa daerah dan hasil penelitian yang dilakukan oleh mahasiswa untuk penyelesaian tugas akhir dalam bentuk skripsi, tesis, atau disertasi. Adapun pendokumentasian yang dilakukan oleh penulis-penulis yang tertarik dengan bahasa Tolaki sangatlah terbatas.

Masyarakat Tolaki adalah masyarakat yang terbuka. Mereka menerima kedatangan etnis-etnis lain dan melakukan penyesuaian diri dengan etnis pendatang. Etnis Tolaki termasuk masyarakat yang ramah dan dapat menerima perbedaan. Jadi, tidak mengherankan jika ada sebagian masyarakat Tolaki menyukai siaran radio yang berbahasa lain.

Penggunaan bahasa Tolaki di media massa hampir tidak pernah terdengar apalagi dibaca. Pada kenyataannya, penggunaan bahasa Indonesia dialek Kendari yang memiliki ciri khas tersendiri dengan intonasi dan karakter penyebutan bunyi tertentu karena pengaruh bahasa Tolaki. Menurut sebagian responden bahwa penggunaan bahasa Tolaki untuk berkomunikasi dalam media sosial terkadang digunakan hanya sebatas ungkapan-ungkapan tertentu. Begitu juga dalam mengiklankan sebuah produk, bahasa Tolaki jarang digunakan karena saat ini etnis Tolaki bukanlah penduduk mayoritas Kendari. Secara umum, tidak ada etnis mayoritas, yang ada ialah etnis yang sudah berbaur yang membentuk Kendari menjadi daerah yang majemuk.

\section{Sikap Bahasa (Kebanggaan dan Kesetiaan)}

Sikap bahasa berkaitan dengan sikap masyarakat tutur terhadap bahasanya. Sikap bahasa adalah posisi mental atau perasaan terhadap bahasa sendiri atau bahasa orang lain. Sikap 
bahasa merupakan faktor penting dalam pemertahanan vitalitas sebuah bahasa. Apabila sikap masyarakat tutur terhadap bahasa positif, bahasa itu dilihat sebagai simbol utama identitas mereka. Sebaliknya, apabila sikap masyarakat tutur terhadap bahasanya negatif, bahasa dipandang sebagai rintangan terhadap mobilitas ekonomi dan integrasi masyarakat maju. Tabel berikut ini memperlihatkan sikap bahasa etnis Tolaki terhadap bahasanya dan sikap bahasa terhadap bahasa Indonesia serta bahasa daerah lain.

Tabel 14

Sikap Bahasa (Kebanggaan dan Kesetiaan Bahasa)

\begin{tabular}{|c|c|c|c|}
\hline Pertanyaan & $\begin{array}{c}\text { Pilihan } \\
\text { Jawaban }\end{array}$ & $\mathbf{F}$ & $\%$ \\
\hline \multirow{3}{*}{$\begin{array}{l}\text { Saudara bangga } \\
\text { berbahasa Tolaki? }\end{array}$} & $\mathrm{Ya}$ & 63 & 98,44 \\
\hline & Tidak & 1 & 1,56 \\
\hline & Total & 64 & 100,00 \\
\hline \multirow{3}{*}{$\begin{array}{l}\text { Saudara menguasai } \\
\text { bahasa Tolaki } \\
\text { dengan baik? }\end{array}$} & $\mathrm{Ya}$ & 39 & 60,94 \\
\hline & Tidak & 25 & 39,06 \\
\hline & Total & 64 & 100,00 \\
\hline \multirow{3}{*}{$\begin{array}{l}\text { Keluarga Saudara } \\
\text { dapat mengguna- } \\
\text { kan bahasa Tolaki } \\
\text { dengan baik? }\end{array}$} & $\mathrm{Ya}$ & 60 & 93,75 \\
\hline & Tidak & 4 & 6,25 \\
\hline & Total & 64 & 100,00 \\
\hline \multirow{3}{*}{$\begin{array}{l}\text { Setiap anggota } \\
\text { kelompok suku } \\
\text { Anda harus } \\
\text { menguasai bahasa } \\
\text { Tolaki? }\end{array}$} & $\mathrm{Ya}$ & 51 & 79,69 \\
\hline & Tidak & 13 & 20,31 \\
\hline & Total & 64 & 100,00 \\
\hline \multirow{3}{*}{$\begin{array}{l}\text { Kelompok suku } \\
\text { Tolaki mempunyai } \\
\text { peran penting dalam } \\
\text { pemerintah-an di } \\
\text { Kota Kendari? }\end{array}$} & $\mathrm{Ya}$ & 59 & 92,19 \\
\hline & Tidak & 5 & 7,81 \\
\hline & Total & 64 & 100,00 \\
\hline \multirow{3}{*}{$\begin{array}{l}\text { Kelompok suku } \\
\text { Tolaki mempunyai } \\
\text { peran penting dalam } \\
\text { kebudayaan di Kota } \\
\text { Kendari? }\end{array}$} & $\mathrm{Ya}$ & 60 & 93,75 \\
\hline & Tidak & 4 & 6,25 \\
\hline & Total & 64 & 100,00 \\
\hline \multirow{3}{*}{$\begin{array}{l}\text { Kelompok suku } \\
\text { Tolaki mempunyai } \\
\text { peran penting dalam } \\
\text { perdagangan di } \\
\text { Kota Kendari? }\end{array}$} & $\mathrm{Ya}$ & 50 & 78,13 \\
\hline & Tidak & 14 & 21,87 \\
\hline & Total & 64 & 100,00 \\
\hline \multirow{3}{*}{$\begin{array}{l}\text { Kelompok suku } \\
\text { Tolaki mempunyai } \\
\text { peran penting dalam } \\
\text { pertanian di Kota } \\
\text { Kendari? }\end{array}$} & $\mathrm{Ya}$ & 57 & 89,06 \\
\hline & Tidak & 7 & 10,94 \\
\hline & Total & 64 & 100,00 \\
\hline
\end{tabular}

\begin{tabular}{|c|c|c|c|}
\hline \multirow{3}{*}{$\begin{array}{l}\text { Bahasa Tolaki } \\
\text { dianggap bahasa } \\
\text { paling penting di } \\
\text { Kota Kendari? }\end{array}$} & $\mathrm{Ya}$ & 53 & 82,81 \\
\hline & Tidak & 11 & 17,19 \\
\hline & Total & 64 & 100,00 \\
\hline \multirow{3}{*}{$\begin{array}{l}\text { Bahasa Tolaki lebih } \\
\text { penting daripada } \\
\text { bahasa daerah lain? }\end{array}$} & $\mathrm{Ya}$ & 31 & 48,44 \\
\hline & Tidak & 33 & 51,56 \\
\hline & Total & 64 & 100,00 \\
\hline \multirow{3}{*}{$\begin{array}{l}\text { Bahasa Tolaki harus } \\
\text { digunakan dalam } \\
\text { kegiatan kesenian } \\
\text { dan adat? }\end{array}$} & $\mathrm{Ya}$ & 57 & 89,06 \\
\hline & Tidak & 7 & 10,94 \\
\hline & Total & 64 & 100,00 \\
\hline \multirow{3}{*}{$\begin{array}{l}\text { Bahasa Tolaki } \\
\text { memberi manfaat } \\
\text { daripada bahasa } \\
\text { daerah lain? }\end{array}$} & $\mathrm{Ya}$ & 29 & 45,31 \\
\hline & Tidak & 35 & 54,69 \\
\hline & Total & 64 & 100,00 \\
\hline \multirow{3}{*}{$\begin{array}{l}\text { Saudara } \\
\text { memperoleh banyak } \\
\text { manfaat dari bahasa } \\
\text { Tolaki? }\end{array}$} & $\mathrm{Ya}$ & 58 & 90,63 \\
\hline & Tidak & 6 & 9,37 \\
\hline & Total & 64 & 100,00 \\
\hline \multirow{3}{*}{$\begin{array}{l}\text { Bahasa daerah lain } \\
\text { menghambat } \\
\text { perkembangan } \\
\text { bahasa Tolaki? }\end{array}$} & $\mathrm{Ya}$ & 7 & 10,94 \\
\hline & Tidak & 57 & 9,06 \\
\hline & Total & 64 & 100,00 \\
\hline \multirow{3}{*}{$\begin{array}{l}\text { Penduduk Kota } \\
\text { Kendari lebih } \\
\text { banyak yang } \\
\text { berbahasa Tolaki } \\
\text { daripada bahasa } \\
\text { daerah lain? } \\
\end{array}$} & $\mathrm{Ya}$ & 28 & 43,75 \\
\hline & Tidak & 36 & 56,25 \\
\hline & Total & 64 & 100,00 \\
\hline \multirow{3}{*}{$\begin{array}{l}\text { Bahasa Tolaki perlu } \\
\text { diajarkan di } \\
\text { sekolah? }\end{array}$} & $\mathrm{Ya}$ & 57 & 89,06 \\
\hline & Tidak & 7 & 11,94 \\
\hline & Total & 64 & 100,00 \\
\hline \multirow{3}{*}{$\begin{array}{l}\text { Bahasa Tolaki } \\
\text { menunjukkan } \\
\text { identitas Saudara? }\end{array}$} & $\mathrm{Ya}$ & 59 & 92,19 \\
\hline & Tidak & 5 & 7,81 \\
\hline & Total & 64 & 100,00 \\
\hline \multirow{3}{*}{$\begin{array}{l}\text { Menggunakan } \\
\text { bahasa Tolaki bagi } \\
\text { Saudara lebih utama } \\
\text { dibanding-kan } \\
\text { dengan bahasa lain } \\
\text { yang Saudara } \\
\text { kuasai? }\end{array}$} & $\mathrm{Ya}$ & 35 & 54,69 \\
\hline & Tidak & 29 & 45,31 \\
\hline & Total & 64 & 100,00 \\
\hline \multirow{3}{*}{$\begin{array}{l}\text { Jika Saudara } \\
\text { berbicara dengan } \\
\text { penutur bahasa lain } \\
\text { yang memahami } \\
\text { bahasa Tolaki, } \\
\text { apakah Saudara } \\
\text { memilih } \\
\text { menggunakan } \\
\text { bahasa Tolaki? } \\
\end{array}$} & $\mathrm{Ya}$ & 44 & 68,75 \\
\hline & Tidak & 20 & 31,25 \\
\hline & Total & 64 & 100,00 \\
\hline \multirow{5}{*}{$\begin{array}{l}\text { Semua penutur } \\
\text { bahasa Tolaki } \\
\text { bangga terhadap } \\
\text { penggunaan bahasa } \\
\text { mereka? }\end{array}$} & $\mathrm{Ya}$ & 56 & 87,50 \\
\hline & Tidak & 8 & 12,50 \\
\hline & Total & 64 & 100,00 \\
\hline & Tidak & 3 & 4,69 \\
\hline & Total & 64 & 100,00 \\
\hline Penutur bahasa lain & $\mathrm{Ya}$ & 60 & 93,75 \\
\hline
\end{tabular}




\begin{tabular}{l|c|c|c}
\hline menghargai bahasa & Tidak & 4 & 6,25 \\
\cline { 2 - 4 } ibu Saudara? & Total & $\mathbf{6 4}$ & $\mathbf{1 0 0 , 0 0}$ \\
\hline $\begin{array}{l}\text { Penggunaan bahasa } \\
\text { Tolaki }\end{array}$ & Ya & 15 & 23,44 \\
\cline { 2 - 4 } $\begin{array}{l}\text { mempermudah } \\
\text { Anda memperoleh } \\
\text { pekerjaan? }\end{array}$ & Tidak & 49 & 76,56 \\
\cline { 2 - 4 } $\begin{array}{l}\text { Penggunaan bahasa } \\
\begin{array}{l}\text { Indonesia } \\
\text { menghambat } \\
\text { perkembangan } \\
\text { bahasa Tolaki? }\end{array}\end{array}$ & Ya & 9 & $\mathbf{1 0 0 , 0 0}$ \\
\cline { 2 - 4 } & Tidak & 55 & 85,94 \\
\cline { 2 - 4 } & Total & $\mathbf{6 4}$ & $\mathbf{1 0 0 , 0 0}$ \\
\hline
\end{tabular}

Sebagian besar anggota

masyarakat tutur bahasa Tolaki menghargai dan mendukung pemertahanan bahasa Tolaki. Hampir semua responden menyatakan bangga terhadap bahasa Tolaki. Kebanggaan bahasa merupakan salah satu karakteristik sikap bahasa yang positif. Rasa bangga terhadap bahasa akan memotivasi penutur untuk mengembangkan bahasanya sebagai simbol identitas dan pemersatu masyarakat.

Selain kebanggaan, juga dapat dilihat dari beberapa sisi lain berdasarkan poin pertanyaan dalam tabel, di antaranya jawaban responden mengenai penguasaan bahasa Tolaki dengan baik, adanya peran suku Tolaki dalam pemerintahan, kebudayaan, perdagangan, dan pertanian. Namun, menurut sebagian responden bahwa bahasa Tolaki penting tetapi bahasa daerah lain juga penting di Kendari. Jadi, etnis Tolaki tidak menganggap bahasanya lebih tinggi daripada bahasa daerah lain, ada perasaan saling menghargai. Begitu halnya dengan pertanyaan, apakah bahasa daerah lain menghambat perkembangan bahasa Tolaki? Secara umum, dijawab dengan tidak setuju. Responden menganggap bahwa bahasa Tolaki hidup berdampingan dengan bahasa daerahbukan saling menghambat. tetapi saling memengaruhi. Begitu juga dengan pertanyaan, apakah bahasa Tolaki memberi manfaat daripada bahasa daerah lain? Sebagian menjawab "tidak" karena menurut responden masingmasing bahasa daerah punya wilayah masing-masing dari segi manfaat.

Berikutnya, berdasarkan pengakuan responden bahwa etnis Tolaki juga bersikap positif terhadap bahasa Indonesia. Selain responden bisa berbahasa Indonesia dengan baik, mereka juga menganggap bahasa Indonesia bukanlah penghambat perkembangan bahasa Tolaki. Setiap bahasa harus dikembangkan dan dilestarikan oleh penuturnya masingmasing. Jika ada etnis yang abai dan lalai terhadap keberadaan bahasa daerahnya, itu berarti kesalahan ada pada penutur bahasa itu.

\section{PENUTUP}

Tingkat vitalitas bahasa penutur bahasa Tolaki di Kota Kendari umumnya tidak jauh berbeda di antara kedua belas indikator. Dari dua belas indikator tersebut, yang tertinggi adalah kedwibahasaan pada indeks 0,74 (stabil, mantap, berpotensi mengalami kemunduran) dan yang terendah adalah pendidikan berada pada indeks 0,05 (sangat terancam). Indeks lainnya secara rerata berada di kisaran angka 0,36 dengan kategori terancam.

Bahasa Tolaki di Kota Kendari sudah jarang digunakan di berbagai ranah kehidupan sosial oleh masyarakat Tolaki. Akses jalan dan transportasi sudah sangat baik sehingga mobilitas penutur Tolaki termasuk tinggi. Mobilitas penutur bahasa lain juga sangat tinggi memasuki kawasan Kota Kendari. Masyarakat penutur Tolaki cenderung dwibahasawan. Bahasa Indonesia menjadi pilihan lain — bahkan utama-dalam melakukan komunikasi, baik interaksi dalam keluarga dan lingkungan sosial. Berbeda pada acara 
adat, bahasa Tolaki masih dipergunakan, khususnya dalam acara pernikahan sesama suku. Masyarakat Tolaki memiliki sikap positif terhadap bahasanya. Mereka merasa bangga dan menganggap bahasa Tolaki masih lebih penting dibandingkan bahasa-bahasa lain. Selain itu, mereka juga menghargai penutur bahasa lain dan keberadaan bahasa lain di Kendari.

Penelitian ini belum secara menyeluruh mewakili pandangan masyarakat Tolaki yang ada di Sulawesi Tenggara. Oleh karena itu, perlu juga dilakukan penelitian vitalitas bahasa Tolaki di wilayah lain, seperti Konawe dan Kolaka.

\section{DAFTAR PUSTAKA}

Aritonang, B. (2016). Kriteria vitalitas bahasa Talondo. Ranah, 5(1), 8 24.

Candrasari, R. (2017). Bahasa Devayan di Pulau Simeulue: Kajian vitalitas bahasa. Universitas Sumatera Utara, Medan.

Crystal, D. (2003). Language death. Cambridge University Press.

Hastuti, H. B. P. (2012). Bahasa Tolaki dari generasi ke generasi: Pergeseran penggunaan bahasa daerah dalam kegiatan mendongeng pada keluarga Suku Tolaki, Aspek-Aspek Bahasa Daerah di Sulawesi Bagian Selatan, 63-77. Hokuto Publishing, Inc.

Ibrahim, G. A. (2011). Bahasa terancam punah: Fakta, sebab-musabab, gejala, dan strategi perawatannya. Linguistik Indonesia, 29(1), 3552.
Inayatusshalihah. (2018). Kajian vitalitas bahasa Adang di Nusa Tenggara Timur. Laporan Penelitian. Badan Pengembangan dan Pembinaan Bahasa.

Lukman. (2012). Vitalitas bahasa: Pergeseran dan pemertahanan bahasa (S. Rabiah (ed.). Makassar: De la Macca.

M.R., D. (2015). Profil kebahasaan nelayan Bugis di Tinobu, Sulawesi Tenggara: Pola-pola penggunaan bahasa. Kandai, Vol. 11(2), 176-188.

Rachmawati, I. (2018). 11 bahasa daerah di Indonesia dinyatakan punah, Apa saja? Kompas. https://regional.kompas.com/read /2018/02/10/18293411/11bahasa-daerah-di-indonesiadinyatakan-punah-apa-saja.

Sumarsono. (2017). Sosiolinguistik. Yogyakarta: Pustaka Pelajar.

Taridala, Y. (2005). Perubahan sosial pada masyarakat Tolaki: Sketsa antropo-sosial di ranah budaya Tolaki. Kendari: Yayasan Hijau Sejahtera.

Tondo, F. H. (2009). Kepunahan bahasabahasa daerah: Faktor penyebab dan implikasi etnolinguistis. Jurnal Masyarakat Dan Budaya, 11( 2), 277-295.

Wagiati, Wahya, dan S. R. (2017). Vitalitas bahasa Sunda di Kabupaten Bandung. Litera, 16(2), 309-317.

Zahari, M. (2011). Menjunjung bahasa persatuan. Jakarta: PT Gria Media Prima. 